\section{Evolution and feasibility of decentralized concentrating solar thermal power systems for modern energy access in rural areas}

Amy Mueller and Matthew Orosz, Parsons Laboratory, Department of Civil and Environmental Engineering, Massachusetts Institute of Technology, Cambridge, Massachusetts, 02139, USA

Arun Kumar Narasimhan and Rajeev Kamal, Clean Energy Research Center, Department of Chemical Engineering, University of SouthFlorida, Tampa, Florida, 33613, USA

Harold F. Hemond, Parsons Laboratory, Department of Civil and Environmental Engineering, Massachusetts Institute of Technology, Cambridge, Massachusetts, 02139, USA

Yogi Goswami, Clean Energy Research Center, Department of Chemical Engineering, University of SouthFlorida, Tampa, Florida, 33613, USA

Address all correspondence to Amy Mueller at amym@mit.edu

(Received 21 September 2015; accepted 13 April 2016)

\title{
ABSTRACT
}

The desire of the international community to balance global economic growth against concerns of accelerated $\mathrm{CO}_{2}$ emissions has brought solar technologies into the forefront for meeting increasing energy demands. This manuscript discusses the historical and potential future roles for small-to-medium scale solar thermal technologies in addressing the challenge of leveling energy access standards across countries with widely variable economic resources and consumer needs.

Access to modern energy services, such as heating for water, pumping for agricultural irrigation or potable water sources, and an on-demand 24/7 electrical grid, is central to provision of high quality social services, economic growth, and improved quality of life; however, over 1 billion people remain unelectrified globally. Enabling the projected growth in energy demands without relying on fossil fuels requires consideration of the viability of renewable energy technologies to serve these markets; this manuscript provides a discussion of the role of solar thermal energy systems in this capacity. A survey of systems under $1 \mathrm{MW}$ capacity reported in the literature (academic and commercial) was conducted, with projects aggregated by service type (heat, cooling, electricity, or multi-) in the database provided as an appendix to this manuscript. In general, many hardware configurations have been explored, with economics driven substantially by supply chain pricing, and no clear winner has emerged. Process heat applications demonstrate economic competitiveness over a wide range of commercial applications; however, early explorations into power generation —or co/tri-generation configurations—provide indications that such technologies, while not expected to reach grid-parity tariffs, may in fact provide the most economical pathway to energy delivery in the currently most underserved communities.

Keywords: energy generation; energy storage; sustainability 


\section{DISCUSSION POINTS}

- Innovations in the field of photovoltaic (PV) have proliferated in the last two decades, however similar price improvements in battery technology has lagged despite substantial investment in this area; how might we envision the design of off-grid systems to adaptively take advantage of battery storage if/when these prices start to fall?

- The US took an all-inclusive approach to electrification, despite the unfavorable economics of reaching sparsely distributed homes far from urban centers; are there areas of the earth not yet electrified where it may make more sense to make islanded energy systems the ultimate goal?

\section{Introduction and background}

Access to modern energy services, such as heating for water, building climate control, and an on-demand 24/7 electrical grid, is central to provision of high quality social services (health, education, treated public water supplies), to economic growth (irrigation for agriculture, mechanized mills and food processing centers, industrial facilities), and to attainment of improved quality of life (indoor lighting and plumbing, small business development). The clear connection between electricity delivery and improved living conditions ${ }^{1}$ has led to a wide range of international initiatives and targets for improved energy access, such as the Millennium Development Goals, ${ }^{2}$ the United Nation's Sustainable Energy for All Initiative, the Lighting Africa effort led by the World Bank and the International Finance Corporation, ${ }^{3-5}$ and the U.S. Power Africa Initiative. The desire of the international community to balance global economic growth against concerns of accelerated $\mathrm{CO}_{2}$ emissions has brought solar technologies into the forefront for meeting this growth in energy demand. This manuscript discusses the historical and potential future roles for small-to-medium scale solar thermal technologies in addressing the challenge of leveling energy access standards across countries with widely variable economic resources and consumer needs.

\section{Energy delivery challenge}

Currently, 1.1 billion people remain unelectrified globally; over half reside on the Africa continent and nearly $30 \%$ live in India, the single largest underserved market, ${ }^{6}$ although these numbers may be underestimated, given the widely varying definitions of 'electrification'. Currently no standard threshold exists in energy (or power) consumed by (or available to) a household to constitute 'electrified', ${ }^{7}$ and therefore while the North American $99 \%$ electrification rate does imply that nearly all households have as much power as they require at all times, the statistics on other continents may refer to households with a single light bulb, a $4 \mathrm{~W}$ solar panel, ${ }^{8,9}$ or a defunct grid connection. For instance, under the India Rajiv Gandhi Grameen Vidyutikaran Yojana (RGGVY) rural electrification scheme, put in place in 2005 , any village with more than $10 \%$ households and all public places connected to the electrical grid is considered 'electrified' regardless of the number of kilowatt-hours delivered ${ }^{10,11}$; in fact, many such villages in Bihar receive 5 or fewer hours of active connection, while urban connections may achieve $24 \mathrm{~h}$ availability. ${ }^{12}$ One effort to overcome the challenges in defining and modeling complex energy access scenarios has been the proposal of a multitiered multiattribute matrix ranking access from tier 0 through tier 5 according to progress along dimensions of capacity, availability, affordability, etc for both electricity and cooking energy. ${ }^{13}$ Weighting between the tiers is a possible means of developing an energy access index. In practice, the use and availability of diverse forms of energy (e.g., kerosene, coal, or biomass for lighting, heating, or cooking) are only poorly studied, and global statistics comparable to those for electrification are lacking.

Energy-poor communities tend to be rural, often in areas with difficult or mountainous terrain, and the institutions (health clinics, schools, police stations, community centers) serving these communities also tend to lack access to electricity. Studies have identified, in particular, high grid connection fees, low population density, low income levels (corresponding to lower demand), and poor/aging transmission and distribution infrastructure as key challenges inhibiting grid extension projects in these areas. ${ }^{14}$ In flat terrain, grid extension typically costs over 10k USD per km; in mountainous terrain, the cost can exceed 20k USD per km. ${ }^{15}$ Because of the aforementioned difficulties in quantification of unelectrified communities, estimates of unelectrified rural institutions may serve as a reasonable lower bound for understanding the magnitude of the remaining challenge: as of 2013 over 80,000 health clinics and 250,000 schools remained in this category. ${ }^{16}$

In an effort to overcome these disparities in service availability, countries across sub-Saharan Africa have set ambitious electrification targets, e.g., $22 \%$ by 2022 in Uganda, ${ }^{17} 35 \%$ by 2020 in Lesotho, ${ }^{18,19} 40 \%$ by 2024 in Kenya, ${ }^{3} 75 \%$ by 2035 in Tanzania. ${ }^{20}$ However, it is widely recognized that meeting these goals will require considering nontraditional (i.e., other than grid extension) options for electrifying rural communities, and many of these countries have specifically committed to the inclusion of community-scale renewable energy systems in their growth portfolios. ${ }^{3,17}$ Correspondingly, in November 2014, the Government of India introduced the Deendayal Upadhyaya Gram Jyoti Yojana initiative, aimed at enhancing the rural distribution and transmission infrastructure and development of off-grid and microgrid networks, and the related Jawaharlal Nehru National Solar Mission scheme announced in 2010 that it specifically targets 2000 MW of off-grid solar power by 2022. ${ }^{21,22}$ Solar thermal, or concentrating solar power (CSP) systems are unique in utilizing thermal energy storage (TES) as an alternative to electrical storage via batteries, and may be appropriate for integration with some community-scale systems, making this a relevant, timely topic for reflection and consideration in this review.

\section{Technological and market context}

Any discussion of the role of CSP technologies within the energy access market requires a definition of both the extent and timing of demand and an understanding of competing 
generation and storage solutions and their costs, summarized briefly here. As noted above, grid extension is generally understood to be uneconomical for serving certain isolated rural communities, and thus this section focuses on alternate technologies that can be deployed in an 'islanded' configuration.

Fossil fuel (usually diesel-powered) generators and solar PV panels are the two technologies typically considered for such applications, although biomass solutions have become more widely used in India in past decades as well (wind and hydro are deployed on a more limited case by case basis depending on local resources). Generators that operate from widely available fuel energy sources are appealing for their load following ability, low capital cost, and high availability (capacity factor > 0.95), however, volatile and rising fuel costs, combined with the tendency for plants to be operated at part-load levels where efficiencies are low, lead to high O\&M and overall levelized electricity costs (typically 0.55 up to $3.33 \mathrm{USD} / \mathrm{kW} \mathrm{h}$ (Refs. 16, 23 and 24) for countries without highly subsidized domestic oil supplies). Further use of diesel power exacerbates $\mathrm{CO}_{2}$ and particulate emissions associated with growth in energy demand. Biomass-based generation offsets some concerns and price prohibitions of diesel generation [prices projected under $0.29 \mathrm{USD} / \mathrm{kW}$ h by the International Renewable Energy Agency in 2012 (Ref. 25)] but is victim to fluctuating prices in fuel stocks and is in direct competition with food supplies, and has not gained substantial traction in the commercial market to date. PV panels with load following DC-AC inverters mitigate point of use pollution concerns and have negligible O\&M costs but require a substantial capital investment; the 75\% decrease in PV module prices from 2009 to 2014 (Ref. 26) places levelized costs for community-scale systems with limited storage around 0.27-0.80 USD/kW h (Refs. 16 and 23) (installed price, which includes PV panels, batteries, and labor; variance due to regional pricing and range of solar resource availability). In contrast, however, household solar home systems (SHS), typically very small per-home capacity and sold as ready-toinstall packages (one time fee) or through a "pay-as-you-go" fee-for-service model (monthly fee), experience prices from 0.85 to upwards of 2.5 USD/kWh (Refs. 27 and 28) if fees are calculated on a per-kW $h$ basis. While in many cases, solar PV may still be the most cost-effective option for electricity provision, especially during daylight hours, the ability to supply all or a high fraction of demand (including nighttime and during cloudy weather) necessitates the use of energy storage via batteries, which are relatively expensive (see section "Applications, economics, and analysis" below). Meeting other energy needs (hot water, air conditioning, etc.) remains uneconomical using PV technology. ${ }^{29}$

\section{Historical role of solar thermal technologies in rural service delivery}

\section{Small-to-medium scale solar thermal technology overview}

Solar thermal systems encompass a wide range of technologies that all broadly rely on mechanical systems to collect sunlight as heat, typically via a system of concentrating optics and/or mirrors [then referred to as CST, or concentrating solar thermal
(CST), systems]. Either by reflection or refraction, incident direct normal irradiance (DNI) is concentrated onto a receiver area (either a focal point or focal line) thereby inducing a temperature rise of the receiver surface [also known as the heat collection element (HCE)], which heats up a process, frequently via a heat transfer fluid (HTF) flowing through it. ${ }^{30}$ Thermal energy collected in the HTF is used for heating applications (industrial processes, space heating, etc.), cooling applications (absorption chillers, ice making), or for extracting mechanical work using a heat engine [steam Rankine cycle, organic Rankine cycle (ORC), or Stirling], the latter usage being typically referred to as CSP. Importantly, between collection and conversion, thermal energy can be stored in a technically straightforward, scaleable, and inexpensive way in comparison to chemical storage of electricity in batteries. The use of TES rather than batteries in islanded systems has potential cost and maintenance advantages for load following applications under conditions of variable insolation. While several CSP and TES technologies are available at the utility (multi-MW) scale, ${ }^{31-34}$ Table 1 contains an overview of the types of solar thermal technologies typically used in or considered for rural energy delivery applications (electricity production and noncooking thermal applications). For this study, we restrict our analysis to systems sized up to $1 \mathrm{MW}_{\mathrm{e}}$ (electricity applications) or $1 \mathrm{MW}_{\text {th }}$ (thermal applications), a size range we designate as 'micro-CSP' (a term first coined by commercial player Sopogy, which exited the 'micro-CSP' market in 2013 after a decade of operation and over 30 installations ${ }^{35}$ ). It should be noted that this cutoff is arbitrary but corresponds roughly to the smallest size potentially considered as viable for utility-scale generation (e.g., the $1 \mathrm{MW}_{\mathrm{e}}$ Saguaro Power Plant in Arizona, USA ${ }^{36}$ ) as well as the size above which technologies utilized tend to be more proven (higher technology readiness level), e.g., turbines developed for use in coal power plants, and operational revenues are high enough to justify numerous on-site staff (a resource that would be too costly for most smaller rural applications that may demand a higher level of automation).

\section{Multifaceted applications of concentrating solar systems}

The range of solar concentrators in Table 1 provides opportunities to meet community needs for hot water or steam generation for process heat, ${ }^{37-93}$ thermal energy for air-conditioning using absorption technologies, ${ }^{94-116}$ and generation of electricity using a heat engine. ${ }^{36,117-174}$ Figure 1 shows typical block diagrams of these processes. It is significant to note that a subset of these processes requires cooling (either air cooling or water cooling) and may therefore present additional demands on the environment in which they are installed; while water demands are not discussed in detail in this manuscript (due to a lack of published information on this topic), one must recognize the importance of considering this variable for installations in drought-prone or water-limited areas.

An inventory of historical, commercial, precommercial pilot, and research solar thermal installations described in the literature is provided as Appendix A (Tables A-1-A-4). This list includes solar thermal projects identified under 1 MW capacity 
Table 1. Small-to-medium scale concentrating solar technologies.

\begin{tabular}{l|c|c|c}
\hline Technology & \multicolumn{1}{c}{ Tracking } & Concentration ratio \\
\hline PTCs & Line & Single-axis (E-W) or (N-S) & $15-45$ (Ref. 226) \\
\hline Paraboloid dish & Point & Dual-axis & Up to 1000 \\
\hline Scheffler dish (elliptical, sub-paraboloid) & Point & Single-axis (E-W) & 125 \\
\hline Linear Fresnel concentrators & Line & Single-axis & \multirow{2}{*}{$10-40$ (Ref. 226) } \\
\hline Paraboloid Fresnel concentrators & Point & Dual-axis & Up to 1000 \\
\hline Power tower & Point & Heliostat array (dual-axis) & $1000-10,000$ \\
\hline
\end{tabular}

a)

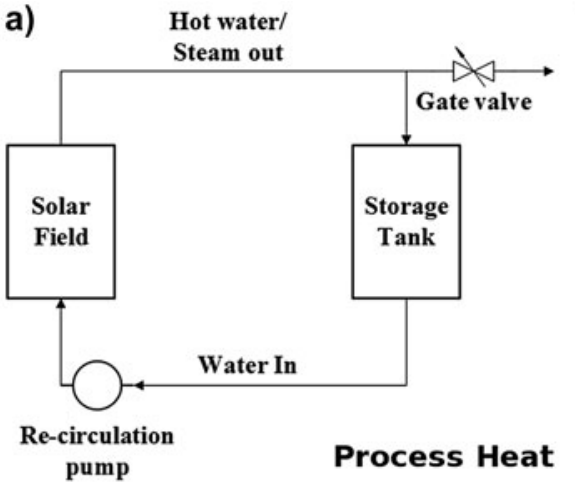

b)

Hot water

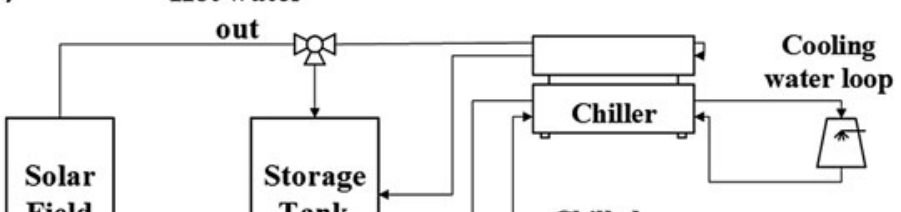

Field

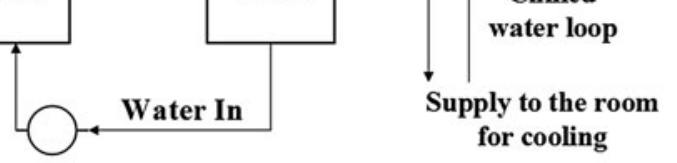

Re-circulation pump

\section{Solar air conditioning}

c)

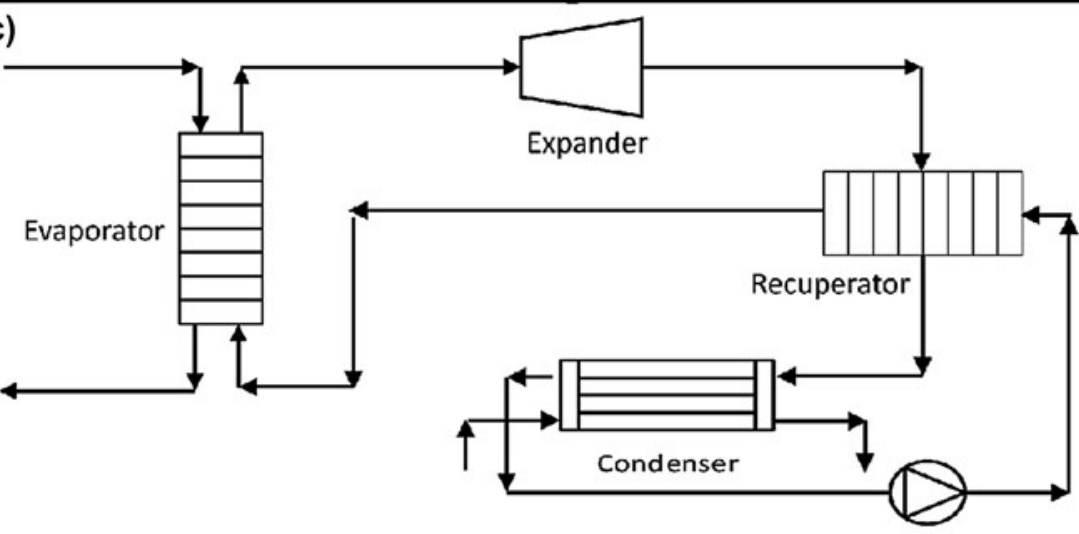

Rankine cycle heat engine

Figure 1. Configurations of typical heat-driven applications of solar thermal technologies.

(excepting those installed as the first phase of a multi-MW project); we have included projects with grid-ties or first-world applications in addition to those explicitly deployed for distributed applications, as such installations may be considered relevant demonstrations for decentralized energy distribution. Absolute project numbers are shown in Table 2 and Fig. 2, while an overview of applications by geography is provided as Fig. 3 .
Several patterns emerge when considering these projects as a portfolio. Although the first solar thermal power plant was successfully demonstrated in Egypt in 1913 (Ref. 175), one must note that commercialization in this market is relatively young, with Scheffler dishes and parabolic trough collectors (PTCs) emerging in the mid-1980s and most other micro-CSP systems being developed in the past 10-15 years; hence, the majority of 
Table 2. Number of solar thermal projects identified, by application type.

\begin{tabular}{l|c|c} 
Application type & Number of projects & Capacity range \\
\hline Electricity & 45 & $<1 \mathrm{~kW}_{\mathrm{e}}$ to $1 \mathrm{MW}$ \\
\hline Cooling & 23 & $17-744 \mathrm{~kW}_{\text {th }}$ \\
\hline Process heat & 43 & $3 \mathrm{~kW}_{\text {th }}$ to $1 \mathrm{MW}_{\text {th }}$ \\
\hline $\begin{array}{c}\text { Co/tri-generation/ } \\
\text { combined }\end{array}$ & 13 & $1 \mathrm{~kW}_{\mathrm{e}}$ to $1 \mathrm{MW}_{\mathrm{e}}$ \\
\cline { 2 - 3 } & & $8-500 \mathrm{~kW}_{\text {th }}$ \\
\hline
\end{tabular}

projects implemented in this field have been commissioned since the year 2000. At the same time, fluctuations in global energy markets (especially in the price of fossil fuels) have created a destabilized demand for solar energy that has resulted in the bankruptcy of many enterprises and rapid turnover in commercial availability of different technologies.

Despite these fluctuations, solar thermal installations used for heat in commercial processes have proven to be economically feasible across a wide range of applications (laundries, dairies, boiler pre-heating, etc.) and scales (10s to $100 \mathrm{~s}$ of $\mathrm{kW}_{\mathrm{th}}$ ) in competitive first-world and even urban markets as evidenced by their rapid expansion and commercial success. These combined characteristics suggest that CST technologies may be well-suited to drive economic growth as well in communities without access to traditional high-volume energy sources (electricity grid, affordable/ subsidized fossil fuel delivery), under appropriate solar resource and application demand conditions. Similarly, solar-driven cooling applications have to date been used primarily by commercial entities as a cost-saving measure to offset heating, ventilation, and air conditioning (HVAC) costs, with the notable exception of the $351 \mathrm{~kW}_{\text {th }}$ system installed at the institutional not-for-profit Muni Seva Ashram College of Nursing hospital in Gujarat, India for similar purposes. In developing markets, the high costs associated with building cooling (regardless of technology type) and the challenges associated with implementing building codes (e.g., ASHRAE 90.1) to ensure human health and safety with respect to indoor temperatures has impeded the scope of CST cooling markets. As the critical importance of human comfort levels in health care and educational outcomes becomes more widely recognized, systems such as the one supporting the Muni Seva hospital will provide a comparable example for a costeffective cooling method that may be deployed to support institutional improvements in regions with good solar resources.

When considering a rural community as a unit, however, it is clear that, while important, neither process heating nor cooling interventions are adequate for achieving energy-access parity with systems similar to those in place in Europe and North America. Especially in sparsely populated regions currently considered as the most promising candidates for decentralized energy services, electricity delivery-to homes, institutions, and businesses-will also be critical to reaching energy access goals:

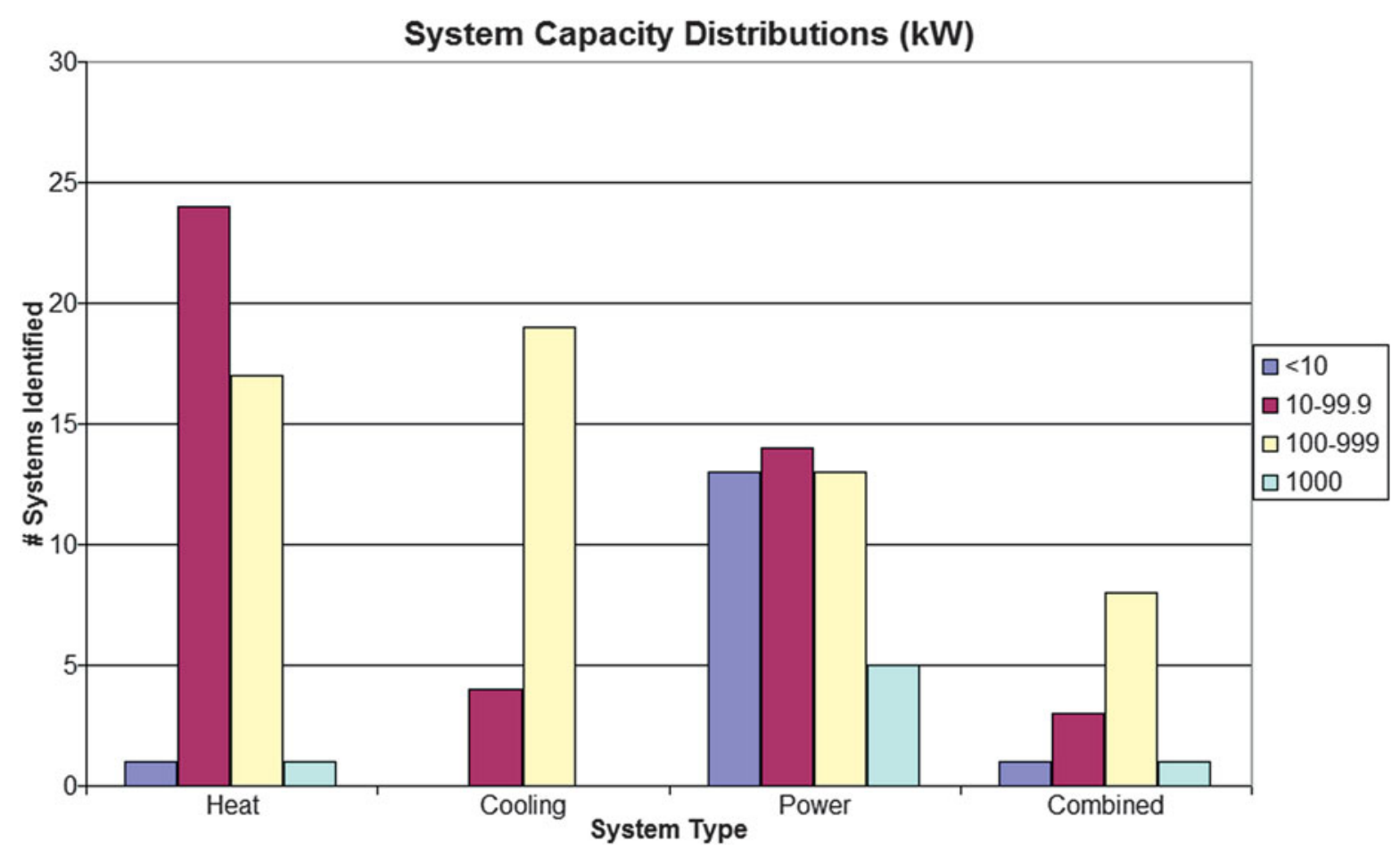

Figure 2. Micro-CSP projects by type and capacity (kW). 


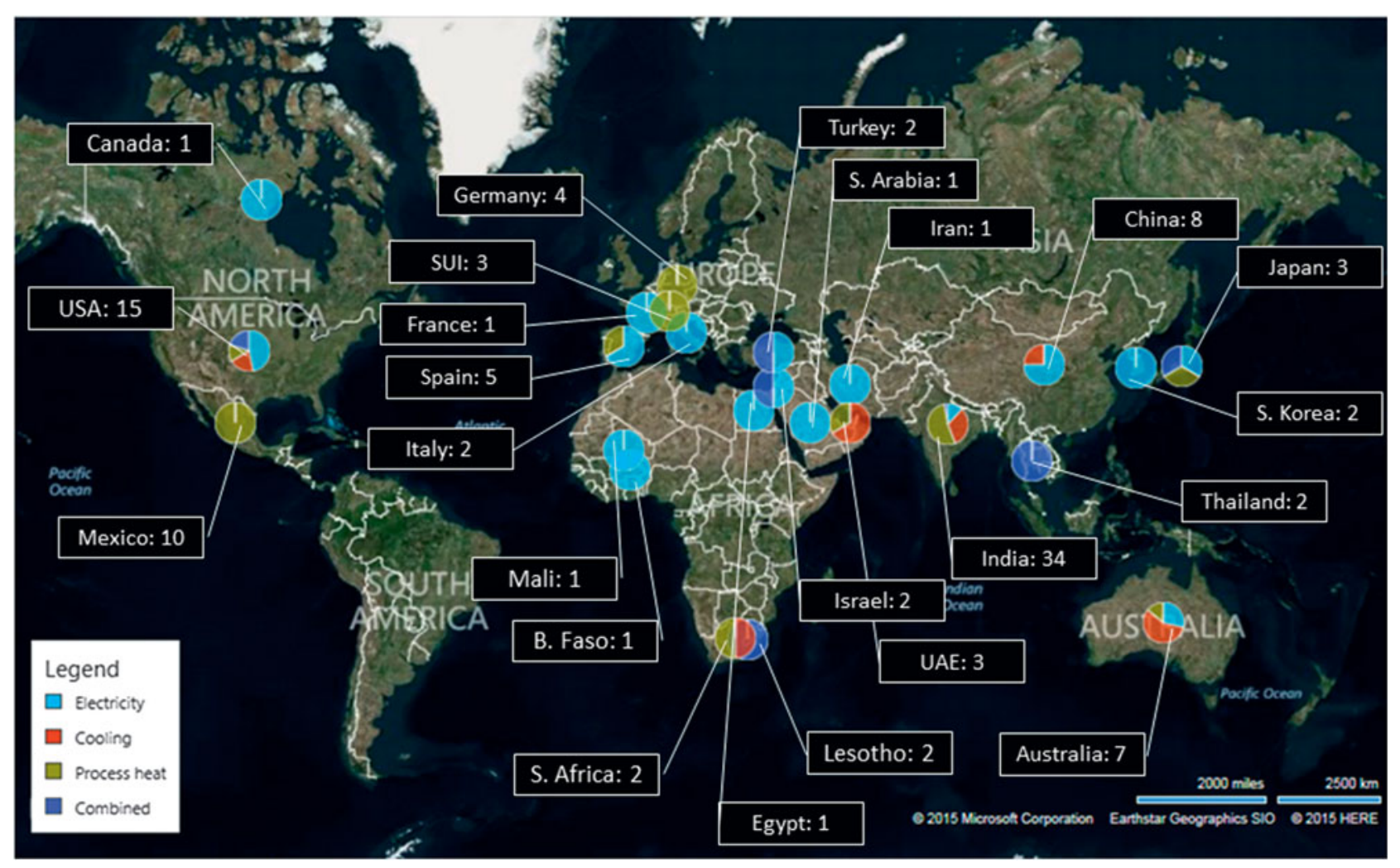

Figure 3. Small-to-medium scale solar thermal projects by location and application type.

for home and exterior security lighting, ventilation, refrigeration, cell-phone charging, irrigation, and powering tools/machines utilized in small businesses. Unlike micro-CST systems for processing heat and cooling applications, micro-CSP systems have not yet been proven economically competitive in existing markets where electricity prices are benchmarked by coal and natural gas generation. For communities sited outside project grid extension territories, however, this metric is unlikely to carry over, and it is thus important to evaluate the potential for use of micro-CSP within the context of this differentiated energy market.

\section{Micro-CSP for distributed electricity generation}

In this review, available published resources were surveyed to gather information on commissioned micro-CSP projects (systems up to $1 \mathrm{MW}$ output capacity as noted above). A total of 124 projects in 25 countries were identified (Fig. 3), and while this inventory may not be comprehensive, it represents the most centralized database available to date. Micro-CSP projects specifically targeting electricity generation (exclusively or as part of a cogeneration or tri-generation scheme also providing heating and/or cooling products) are disadvantaged in comparison to micro-CST applications, in that poor prospects for economic returns in grid-tied markets have restricted development to niche applications and R\&D efforts. Indeed, over 50\% of the systems identified in Appendix A (Tables A-3 and A-4) are explicitly listed as demonstration or R\&D facilities, while fewer than $10 \%$ are considered commercial endeavors (some systems of this nature are explicitly supported by government subsidy for noncommercial uses, and for others information is simply not available). As stated above, however, micro-CSP systems may prove a more competitive option within decentralized energy applications where electricity prices are dictated more commonly by the fuel costs of distributed generators rather than by utility-scale coal plants (the economics are discussed in more detail in the subsequent section). It is thus relevant to understand what progress has already been made in the development of micro-CSP and specifically what results have been achieved in piloting (or deploying) micro-CSP for electricity generation in these target markets. Data for power generation applications were collated from Appendix A by electrical nameplate capacity (presented in Fig. 2). It is particularly noteworthy that systems have been tested and/or deployed at all orders of magnitude to theoretically match the demand profiles of a wide range of rural communities, despite the fact that generally efficiencies and specific (per-unit) costs (levelized electricity cost) are known to improve as plant capacity scales.

Another important consideration in micro-CSP is the power cycle used to convert heat to electricity, e.g., a steam Rankine, organic Rankine, Stirling, or Brayton cycle, as these technologies themselves may be more or less available, efficient, or affordable at different scales. It is clear from Tables A-3 and A-4 
that no market-driven consensus has yet been reached on the optimal technologies to use for either solar collectors or for heatto-electrical conversion; Figs. 4 and 5 highlight the cases where some pattern emerges from analysis of all projects together. To date, parabolic dishes and Stirling engines (typically coupled to take advantage of the high concentration ratios directly at the engine receiver) have tended to be favored in the $<10 \mathrm{~kW}_{\mathrm{e}}$ range, however, a number of different solar collector types (primarily the PTC) have also been coupled with ORC engines at this small scale and no definitive economic winner has yet emerged. In the 10-99 $\mathrm{kW}_{\mathrm{e}}$ range, parabolic troughs and dishes are dominant, coupled with many different cycle configurations customized for the application (with ORC representing about $50 \%$ of projects). Above $1 \mathrm{MW}_{\mathrm{e}}$, the ORC and traditional steam Rankine cycle become the frequent choices of heat engine (likely for cost reasons, as these components are used in other power plants at this scale and are thus available commercially), and PTCs become the more frequent collector choice likely due to and the commercial availability at this scale and relative ease of scalability. In the range of $100 \mathrm{~s}$ of $\mathrm{kW}_{\mathrm{e}}$, however, one finds a variety of system configurations, coupling different cycles and solar collector types. At this scale the temperatures that can be achieved in the solar fields are higher, while total area required is small enough to retain feasibility of solar field assembly out of many types and sizes of solar modules; as such, the economic viability of particular projects may be much more dependent on the local supply chain, experience in labor markets, or other locally driven variables than in the technologies selected for the plant.

\section{Key demonstrations for decentralized applications}

In looking to assess the feasibility and potential of microCST/CSP for distributed applications, it is informative to look both at projects already conducted in the target locations (rural communities with limited energy access via centralized pathways) and those installed as R\&D facilities but with the explicit intention of evaluating the technology for use in decentralized communities (as opposed to R\&D intended eventually to enable utility-scale installations). While heating and cooling applications are also potentially important energy needs in decentralized communities, it is clear from the assembled plant inventory that such projects tend to be driven by industrial, rather than community demands; in contrast, power-producing and cogeneration projects tend to support both community needs and those of closely sited industrial activities. As such this section will focus primarily on electricity and cogeneration, briefly highlighting a few projects (data from Appendix A) that exemplify the potential of micro-CSP for these decentralized applications.

\section{Cycle Type as a Function of System Capacity}

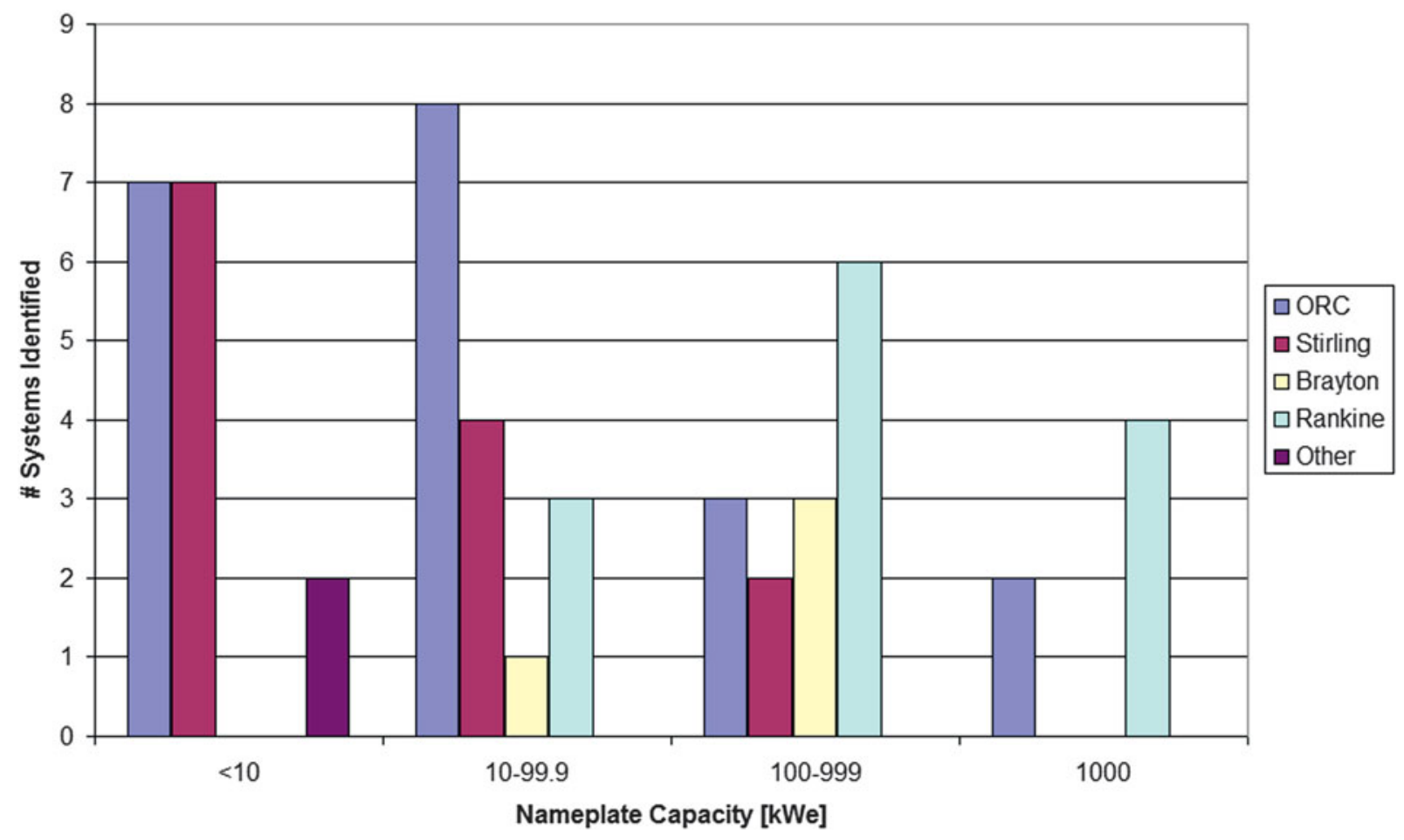

Figure 4. Cycle technologies selected for heat-to-electrical conversion in micro-CSP projects: counts provided for the number of each engine type for four size categories (under 10, 10-99.9, 100-999 $\mathrm{kW}_{\mathrm{e}}$, and $1 \mathrm{MW}_{\mathrm{e}}$ ). Except for the last category which contains systems at only one size (1 MW), other categories aggregate systems over the indicated size range. (Absent bar indicates zero systems with that combination of characteristics.) 


\section{Solar Collector Technology as a Function of System Capacity}

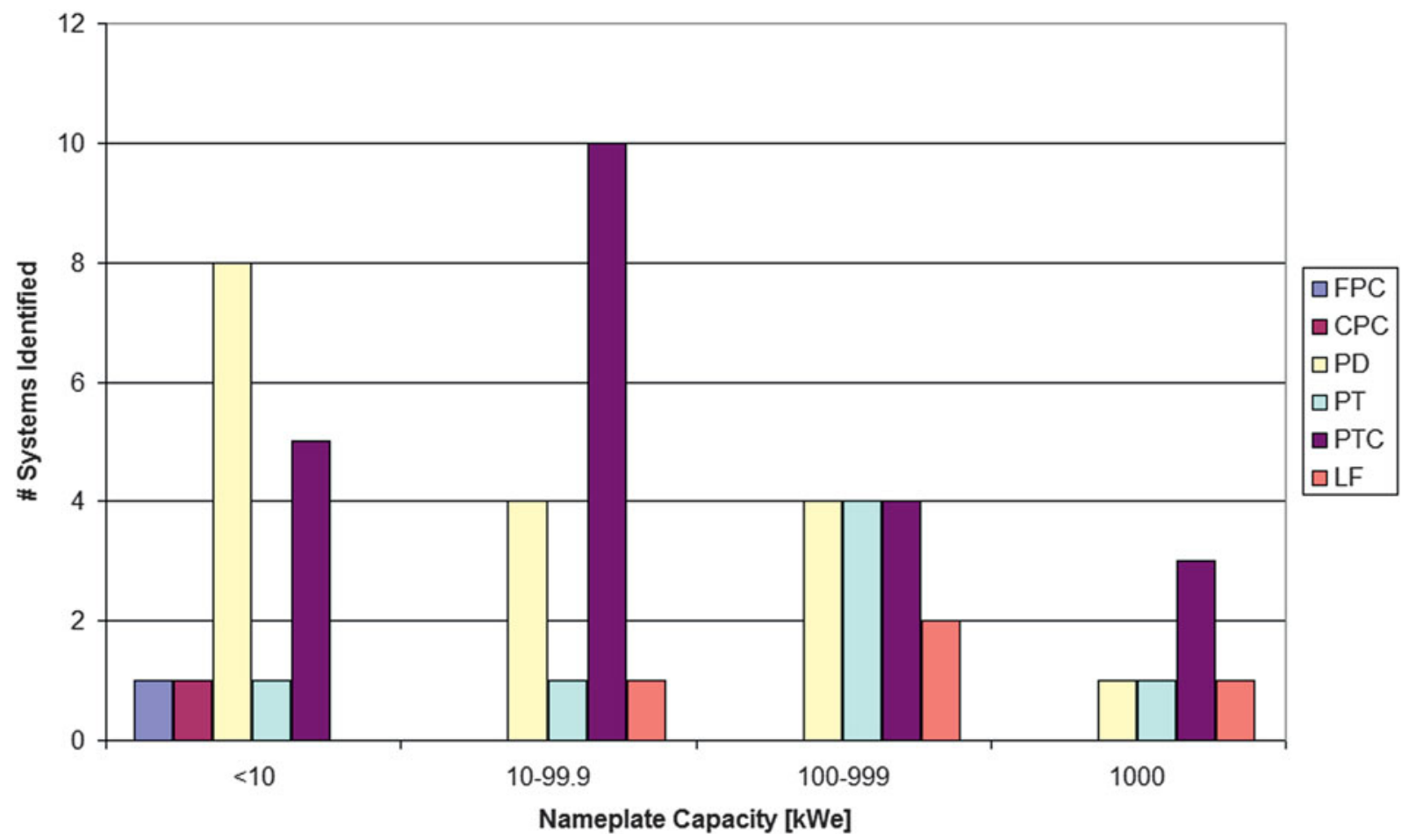

Figure 5. Solar collector technologies selected for heat-to-electrical conversion in micro-CSP projects. $\mathrm{FPC}=$ flat plate collector; $\mathrm{CPC}=$ compound parabolic concentrator; PD = paraboloid dish; PT = power tower; PTC = parabolic trough collector; LF = linear Fresnel.

Two examples constructed in developed nations bracket the range of project sizes that would be expected to serve remote, offgrid communities. At the small end of the range is the $6 \mathrm{~kW}_{\mathrm{e}}$ Solar PTC-ORC system constructed at Commonwealth Scientific and Industrial Research Organisation (CSIRO) (the Australian national science and research agency) in 2006 (Ref. 131); in publications describing the system and results, researchers indicate that "eventual applications are envisaged for both distributed generation (i.e., sited in appropriate locations in suburban communities) and remote power and energy". This end-goal guided system design and consideration of the economics governing system competitiveness as it was explicitly acknowledged that the technology would be competing with, e.g., diesel-driven generation rather than the national grid. (Notably, the $3 \mathrm{~kW}_{\mathrm{e}}$ system constructed in Rome in 1961 had similar motivations and goals.) At the upper end of the micro-CSP range is the $1 \mathrm{MW}_{\mathrm{e}}$ Saguaro Power Plant in Arizona, USA. ${ }^{36}$ This PTC-ORC system was envisioned, at least in part, to explore economic viability at a scale that could serve decentralized communities (expected to require far less power than generated by traditional plants), and while tax credits and renewables regulations in part drove construction of this grid-tied system, the break-even tariffs achieved would easily compete with diesel generation in an off-grid scenario.

Significantly, a number of small solar plants have already been constructed and commissioned for use in decentralized applications (though many as demonstration or R\&D projects). The earliest of these is the $191375 \mathrm{~kW}_{\mathrm{e}}$ PTC-Rankine plant in Egypt ${ }^{117-119}$ which used solar power to displace the need for an alternate fuel source to power water pumps; the $19661 \mathrm{~kW}_{\mathrm{e}}$ flat plate collector (FPC)-ORC plant in Mali ${ }^{120,121}$ had a similar use. In the past decade, interest has grown in solar-driven electricity generation for more general purposes, with systems from 1 to $10 \mathrm{~kW}_{\mathrm{e}}$ being demonstrated on the African continent (in Lesotho by the authors ${ }^{176}$ and Burkina Faso ${ }^{165,166}$ ) using small ORC engines and a range of solar collector types. A larger $\left(100 \mathrm{~kW}_{\mathrm{e}}\right)$ Power Tower-Brayton system was installed in 2009 to serve a community of approximately 230 people living in the desert in Israel; while this system is grid-tied, it does not require the connection. One step more isolated from the grid is the $256 \mathrm{~kW}_{\mathrm{e}}$ hybrid PTC-ORC/biomass plant that provides electricity to Shive, a rural village of approximately 1400 people, near Pune, India. ${ }^{146-148}$ This system also has a grid-tie, and it is used exclusively to serve the community during periods when power is not available from the grid (grid availability a few times per week is scheduled by the utility). In areas where fresh water delivery is unreliable, solar desalination has similarly been considered to replace centralized government/utility services: the desalination plant (using linear Fresnel concentrators) at Narippaiyur, India provides $6000 \mathrm{~L} / \mathrm{h}$ of potable water exclusively for an otherwise underserved rural community. ${ }^{76-79}$ Finally, two projects 
in Thailand highlight the medium-scale potential for cogeneration and tri-generation. The PTC-Rankine system at Phitsanulok

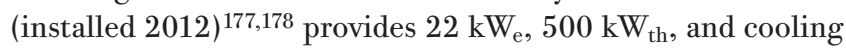
via a single-stage chiller, and was designed "to demonstrate an innovative technology for the decentralized provision of electrical energy, heat, and air conditioning from solar energy and biomass and to introduce it to potential cooperation partners in the region of Southeast Asia." The PTC-Rankine system installed at Chonburi in 2006 (Refs. 179 and 180) further integrates biomass hybridization to enable night-time generation, providing approximately $10 \mathrm{~kW}_{\mathrm{e}}$ and $100 \mathrm{~kW}_{\text {th }}$. Like the projects in Lesotho, Burkina Faso, and Shive, the Chonburi project design further included the goal "to demonstrate the possibility of simple operation that can be carried out by local community staff."

Taken together, these initiatives demonstrate an awareness of a service gap and provide initial examples of ways in which micro-CST/CSP has a potentially important role to play for decentralized communities. In many cases (e.g., hybridization with biomass to enable energy supply at night or in rainy seasons, or co-generation applications) providing a similar service using PV panels is either infeasible or would have be prohibitively expensive. It is thus critical when assessing projects for these applications to consider the true alternative options to determine economic competitiveness and to examine the existing (often lacking) solutions for an appropriate benchmark in ability and willingness of the customer to pay.

\section{Applications, economics, and analysis}

Suitable applications for micro-CSP systems include situations where either heat alone or combined heat and power are needed, where there is a potential supplementary thermal resource available (biomass combustion, industrial waste heat, or even internal combustion generator exhaust waste heat to recover), or where the interaction between solar availability and load dynamics favors low cost TES over extensive use of batteries in 'islanded' systems. The factors that influence the decision to deploy any particular type of energy solution include the total cost (capital, operation and maintenance) and performance, both of which are mediated by local conditions (markets, meteorology, etc.). Szabo et al. ${ }^{23}$ used a mapping methodology to overlay the differential costs of competing electrification schemes (distributed solar, diesel, and grid extension) in rural Africa using geographically determined diesel prices and solar insolation. A similar exercise is yet to be performed for microCSP, although Orosz et al. ${ }^{29}$ presented a comparison of PV, micro-CSP, and diesel hybrid systems for cogeneration deployment at health centers in Africa as a function of latitude.

While commercial capital costs of micro-CSP systems are generally unavailable due to a lack of standardization and long-term benchmarking in the market, estimates based on plausible component costs range upwards from $4.7 \mathrm{USD} / \mathrm{W}$ for a micro-CSP system without TES to 8.4 USD/W for a system with $6 \mathrm{~h}$ of storage and a solar multiple of 1.3 and 2 , respectively-however, specific cost of power can be misleading in terms of the realized specific cost of energy, which for the above cases (assuming cumulative energy generated over 15 years operation) would be $0.11 \mathrm{USD} / \mathrm{kW}$ h without storage and $0.07 \mathrm{USD} / \mathrm{kW} \mathrm{h}$ with TES (the difference being due to the higher capacity factor and amortization of the power block over total energy output). The following supporting assumptions were used to arrive at these estimates: $220 \mathrm{USD} / \mathrm{m}^{2}$ for solar collectors ${ }^{181}$ (and vendor quotations), $800 \mathrm{~W} / \mathrm{m}^{2} \mathrm{DNI}$ for peak solar resource, $70 \% \mathrm{HCE}$ thermal efficiency, ${ }^{182}$ and $21 \%$ power block efficiency (ChambadalNovikov efficiency assuming a $10{ }^{\circ} \mathrm{C}$ temperature pinch and source and sink temperatures of 250 and $35^{\circ} \mathrm{C}$, respectively ${ }^{183}$ ) with a specific cost of 1.5 USD/W for the power block, $22.5 \mathrm{USD} / \mathrm{kW}_{\text {th }}$ for the TES $1.5 \times$ the US DOE Sunshot goal of $15 \mathrm{USD} / \mathrm{kW} \mathrm{h}_{\text {th }}$ (Ref. 184) and within the range of costs identified by IRENA ${ }^{185}$ and $20 \%$ indirect costs. ${ }^{186}$ In comparison, PV specific costs for similar systems would be 1.7 USD/W and 3.8 USD/W for a system with 6 hours storage (useful in the case of PV sunlight-to-electricity systems due to the substantial fraction of most developing country loads that occur in the early evening when the sun is no longer shining) with a 1.3 and 2 solar multiple, respectively, and levelized energy costs over 15 years of 0.04 and $0.07 \mathrm{USD} / \mathrm{kW} \mathrm{h}$ (assuming the battery bank is replaced once). These estimates use the following cost basis from commercially active vendor quotations: a cost including freight and customs to Africa from Chinese PV manufacturers of 0.9 USD/W (320 W mono panels Shanghai, CN to Durban, $\mathrm{ZA}), 110 \mathrm{USD} / \mathrm{kW} \mathrm{h}$ for sealed lead acid batteries (L-16 type), 0.2 USD/W for a charge controller, and 0.15 USD/W for an inverter (plus $20 \%$ indirect costs).

This comparison is simplified and does not capture any divergence between direct and global irradiance in a location, or the fact that as a tracking system the CSP will tend to have a greater energy output than PV for an equivalent peak watt rating (unless the PV is also mounted on a tracker, which is not considered here). Moving from capital to levelized costs requires taking into account any differential in operations and maintenance between micro-CSP and PV, e.g., the lead acid batteries will need replacement within 5-10 years whereas the TES does not, impacting the project finance scenarios. A full system level performance and cash flow analysis is required for every application to validate the financial figure of merit [levelized cost of electricity (LCOE), net present value (NPV), internal rate of return, total cost of ownership, etc.]. (This requirement for costly and repeated application engineering and the fact that there is no "one size fits all" solution for diverse energy access needs is a contributing factor to the persistence of energy access deficits.)

Analysis of the capital and LCOE from a PTC-driven solar ORC (configured for electricity generation alone, i.e., no cogeneration considered) in various regions of Africa was presented by Mitterhofer, ${ }^{187}$ and the use of micro-CSP in hybrid microgrid applications was investigated by Orosz et al. ${ }^{188}$ for a typical 100 household village using Lesotho as a case study with a load profile created from a probabilistic distribution function derived from load measurements in a comparable community in South Africa. In the former case study, which was validated to data from a PTC-ORC plant at Eckerd College in St. Petersburg 
Florida, LCOE in USD/kW h was predicted to be 0.58 in Johannesburg, ZA, 0.72 in Harare, ZW, 0.67 in Addis Ababa, ET, and 1.05 in Nairobi, KE (accounting for variation in ambient temperature and insolation with fixed demand). In the latter study, hybridizing micro-CSP with PVs, batteries, and back up liquid petroleum gas (LPG) generation yielded an optimized tariff of $0.35 \mathrm{USD} / \mathrm{kW} \mathrm{h}$ for the plant. Even under optimistic scenarios, the levelized cost of energy from micro-CSP systems is likely to be 2-3 times higher than the typical on-grid tariff. In 2010, the average effective electricity tariff in Africa was US $\$ 0.14$ per kilowatt-hour ( $\mathrm{kW} \mathrm{h}$ ) (against an average of US $\$ 0.18$ per $\mathrm{kW} h$ in production costs; the discrepancy reflects government subsidy of on grid consumption). ${ }^{189}$ Managing expectations of off-grid consumers and government regulators as to an appropriate cost-recovery scheme or off-grid tariff subsidy will be critical to enabling market entry for micro-CSP platforms in distributed applications. In India, a federal financial subsidy of about $90 \%$ of the capital cost for renewable and hybrid technology based electrification for remote villages is theoretically available to state governments under the Remote Village Electrification program of RGGVY scheme. ${ }^{190}$

None of the micro-CSP plants identified in the inventory were specifically targeted for individual household use, although single institutional systems (health clinics, schools) are represented. The most likely deployment scenarios for micro-CSP include industrial process heat, institutional and community-scale cogeneration applications requiring several to hundreds of kilowatts. In microgrid applications, the hub and spoke topology of electricity distribution networks tends to dictate a break-even household density (number of consumers per $\mathrm{km}$ of wire), where centralized systems would be more appropriate than e.g., individual solar PV home systems (SHS). For the foreseeable future, PV home systems will be less expensive to deploy than comparable output micro-CSP systems. On the other hand, micro-CSP at larger scales in the applications identified above can leverage lower cost of energy storage via TES and the ability to integrate flexibly with both demand and supply thermal processes/resources (e.g., heating loads, or the availability of biomass). Nearly $73 \%$ of sub-Saharan African countries have national average population densities lower than 100 persons $/ \mathrm{km}^{2}$ (as well as low per capita energy consumption), ${ }^{191,192}$ whereas in India the population density in 2013 was 421 persons $/ \mathrm{km}^{2}$ (Ref. 191). While this would seem to indicate that India is a more likely candidate for microgrids, in practice, several determining factors will mediate the applicability of such systems over alternatives such as grid connection or SHS. The proximity of underserved communities to the grid is relatively closer in India than in Africa, where approximately $75 \%$ of people lack energy access. The layout of communities in dispersed agricultural homesteads versus tightly packed village residential centers is also site and region specific. For this reason, satellite or aerial image based mapping and demographic survey integrated planning processes are needed to (i) geo-locate individual household connections, (ii) determine the likely loads using representative baseline data, and (iii) choose the optimal technology solution (grid extension, microgrids, or SHS) able to serve diverse communities given local conditions (DNI versus global irradiance, cost per $\mathrm{km}$ to extend the grid, etc.). For those communities down-selected as microgrid candidates, optimized micro-CSP systems can play an important role in enabling combined heat and power for any institutional or local business process heat needs, while mitigating some of the cost of expensive and limited cycle lifetime battery systems to dispatch energy during nighttime.

\section{Conclusions}

The historical and potential roles for small-to-medium scale solar thermal technologies were reviewed in the context of increasing energy access in off-grid communities. Solar thermal or CSP systems may be appropriate for integration with community-scale systems under certain conditions, such as a demand for process heat, combined heat and power, or load following requirements under variable solar insolation. Experience with deployment of micro-CSP systems was investigated and an inventory of 124 installations across 25 countries was identified with a nearly even mixture of commercial and research pilot projects. The commercial sector for micro-CSP remains immature, characterized by a high level of market player turnover, and lack of standardized systems with long-term operation needed for benchmarking performance and cost.

While in many cases solar PV may be the most cost-effective option for electricity provision, especially during daylight hours, meeting thermal energy needs and coupling with battery storage to maintain output at night and during cloudy weather it remains uneconomical using traditional solar panels. In comparison, micro-CSP systems, while not economically competitive with utility-scale coal and natural gas generation, may be viable in microgrid applications in comparison to equivalent alternatives such as diesel generators or PV coupled with a large battery bank, particularly when the micro-CSP can integrate TES. The economic optimization of particular projects will be driven by features of the specific demand curve of the target application, local supply chain, labor markets, and other locally driven variables such as meteorology. System level analysis and application engineering for each unique situation is therefore necessary to validate the financial figure of merit (LCOE, NPV, internal rate of return, total cost of ownership, etc.) for any distributed generation project. This requirement and the fact that there is no "one size fits all" solution for diverse energy access needs is a contributing factor to the persistence of energy access deficits.

Despite this challenge, optimized community-scale microCSP systems with TES can play an important role in enabling combined heat and power for institutional or local business process heat needs, while mitigating some of the cost and maintenance burden associated with battery systems. Further research, development, and commercialization of micro-CSP technology with specific application to decentralized power applications is justified in light of the commercial and $R \& D$ progress to date and its unique potential for flexible electricity and heat delivery and low cost storage. 


\section{REFERENCES:}

1. Benka S.G.: The energy challenge (2002). Available at: http://scitation. aip.org/content/aip/magazine/physicstoday/article/55/4/10.1063/ 1.1480780 (accessed September 9, 2015).

2. Practical Action: Poor People's Energy Outlook 2013: Energy for Community Services (Practical Action Publishing Ltd, Warwickshire, Rugby, 2013). Available at: http://practicalaction.org/ppeo2013 (accessed November 17, 2014).

3. Lighting Africa: Policy report note: Kenya (2012). Available at: http://www.lightingafrica.org/resources/policy-documents.html (accessed November 12, 2014).

4. Lighting Africa: Policy report note: DR of Congo (2012). Available at: https://www.lightingafrica.org/resources/policy-reports/ (accessed November 16, 2014).

5. Lighting Africa: Policy report note: Tanzania (2012). Available at: http://www.lightingafrica.org/resources/policy-documents.html (accessed November 12, 2014).

6. International Energy Agency: Electricity access database 2014 (2014). Available at: http://www.worldenergyoutlook.org/resources/ energydevelopment/energyaccessdatabase/ (accessed February 21, 2015).

7. International Energy Agency, IEA: Defining and modelling energy access. www.iea.org. Available at: http://www.worldenergyoutlook.org/resources/ energydevelopment/definingandmodellingenergyaccess/ (accessed May 26, 2015).

8. Fehrenbacher K.: How M-KOPA unlocked pay-as-you-go solar in rural Kenya. Gigaom (2014). Available at: https://gigaom.com/2014/04/10/ how-m-kopa-unlocked-pay-as-you-go-solar-in-rural-kenya/ (accessed November 18, 2014).

9. Markham D.: Pay as you go solar power systems provide clean, affordable lighting in Kenya. Treehugger (2013). Available at: http://www. treehugger.com/solar-technology/pay-you-go-solar-power-systems-kenya. html (accessed November 18, 2014).

10. RGGVY: Definition of electrified villages. Rajiv Gandhi Grameen Vidyutikaran Yojn a (2011). Available at: http://rggvy.gov.in/rggvy/ rggvyportal/def_elect_vill.htm (accessed November 19, 2014).

11. Ministry of Power: The Gazette of India extraordinary part-I-Section-1 (2006). Available at: http://powermin.nic.in/JSP_SERVLETS/ internal.jsp\# (accessed November 19, 2014).

12. The Energy and Resources Institute (TERI): Executive summary of RGGVY evaluation (2011). Available at: http://rggvy.gov.in/rggvy/rggvyportal/ evaluation/TERI_Combined_Executive_Summary.pdf (accessed November 19, 2014).

13. Angelou N. and Bhatia M.: Capturing the multi-dimensionality of energy access (Washington D.C., 2014). Available at: http://documents. worldbank.org/curated/en/2014/06/19670596/capturing-multidimensionality-energy-access (accessed September 12, 2015).

14. Barnes D.F.: Draft for discussion: Meeting the challenge of rural electrification in developing nations: The experience of successful programs (2005). Available at: http://siteresources.worldbank.org/ EXTRENENERGYTK/Resources/5138246-1237906527727/ 5950705-1239305592740/Meeting0the0Ch10Discussion0Version0.pdf (accessed November 17, 2014).

15. Foster R., Ghassemi M., and Cota A.: Solar Energy, Renewable Energy and the Environment (CRC press, Taylor \& Francis Group, Boca Raton, FL, USA, 2009). Available at: https://goo.gl/AHKAYk (accessed September 12, 2015).

16. Kazem H.A., Alkurwi A.A., Mohmmed M., Salam A., and Alwaeli A.H.A.: Levelized Electricity Cost for Photovoltaic System in Sohar-Oman (IEEE, Monte Carlo, 2013). Available at: http://ieeexplore.ieee.org/xpls/abs_all. jsp?arnumber=6521534 (accessed September 9, 2015).

17. Ministry of Energy and Mineral Development: The government of the Republic of Uganda: Rural electrification strategy and plan, covering the period 2013-2022 (2012). Available at: http://rea.or.ug/phocadownload/ ruralelectrificationstrategyandplan2013-2022.pdf (accessed November 3, 2014).
18. Ministry of Natural Resources: Annual report-Lesotho renewable energy based rural electrification project (2008). Available at: http://www.gov.ls/ documents/reports/2008_ANNUAL_REPORT-4.pdf (accessed November 9, 2014).

19. United Nations Development Programme: Government of Lesotho: Renewable energy-based rural electrification in Lesotho (2006). Available at: http://198.170.76.94/energy/EEprodoc-projectdocLREBRE-final.pdf (accessed November 9, 2014).

20. Ministry of Energy and Minerals: Power system master plan 2012 update (United Republic of Tanzania, 2013). Available at: http://goo.gl/hdbL3w (accessed November 2, 2014).

21. Ministry of New and Renewable Energy: Jawaharlal Nehru national solar mission-Towards building solar India (2010). Available at: http://www. mnre.gov.in/file-manager/UserFiles/mission_document_JNNSM.pdf (accessed May 20, 2015).

22. Ministry of New and Renewable Energy: Jawaharlal Nehru national solar mission phase II. Available at: http://seci.gov.in/content/innerinitiative/ jnnsm.php (accessed June 18, 2015).

23. Szabó S., Bódis K., Huld T., and Moner-Girona M.: Energy solutions in rural Africa: Mapping electrification costs of distributed solar and diesel generation versus grid extension (2011). Available at: http://stacks.iop.org/1748-9326/6/i=3/a=034002?key=crossref. 89590e74fed5b2bdbff442f147cb9d62 (accessed May 13, 2015).

24. NORPLAN: NORPLAN study: Cost competitiveness of rural electrification solutions (2013). Available at: http://norplan.com/files/2013/05/ NORPLAN-Study-full-article-3-.pdf (accessed September 9, 2015).

25. IRENA-International Renewable Energy Agency: Renewable power generation costs in 2012: An overview (2012). Available at: http://costing. irena.org/media/2769/Overview_Renewable-Power-GenerationCosts-in-2012.pdf (accessed April 1, 2015).

26. IRENA-International Renewable Energy Agency: Renewable power generation costs in 2014 (2014). Available at: http://www.irena.org/ DocumentDownloads/Publications/IRENA_RE_Power_Costs_2014_ report.pdf (accessed May 15, 2015).

27. Simonet E.: Smart energy access: The role of micro-grids (2012). Available at: http://www.renewable-world.org/sites/default/files/Session1Emilio SimonetRenewableWorld-Micro-grids_0.pdf (accessed September 9, 2015).

28. Jenkins G.P.: Off-grid Solar PV: Is it an affordable or an appropriate solution for rural electrification in sub-Saharan African countries? (2014). Available at: http://www.queensjdiexec.org/publications/qed_dp_269.pdf (accessed September 9, 2015).

29. Orosz M.S., Quoilin S., and Hemond H.: Technologies for heating, cooling and powering rural health facilities in sub-Saharan Africa (2013). Available at: http://pia.sagepub.com/lookup/doi/10.1177/0957650913490300 (accessed September 6, 2014).

30. Goswami D.Y.: Principles of Solar Engineering, 3rd ed. (CRC Press, Taylor \& Francis Group, Boca Raton, FL, USA, 2015).

31. Lovegrove K. and Stein W.: Concentrating Solar Power Technology: Principles, Developments and Applications (Woodhead Publishing, 2012). Available at: http://store.elsevier.com/Concentrating-Solar-PowerTechnology/isbn-9781845697693/ (accessed August 23, 2015).

32. Libby C.: Solar thermocline storage systems: Preliminary design study (Palo Alto, 2010). Available at: http://www.epri.com/abstracts/Pages/ ProductAbstract.aspx?ProductId=000000000001019581 (accessed August 23, 2015).

33. Kuravi S., Trahan J., Goswami D.Y., Rahman M.M., and Stefanakos E.K.: Thermal energy storage technologies and systems for concentrating solar power plants. Prog. Energy Combust. Sci. 39, 285-319 (2013). Available at: http://www.sciencedirect.com/science/article/pii/S0360128513000026 (accessed August 23, 2015).

34. Stekli J., Irwin L., and Pitchumani R.: Technical challenges and opportunities for concentrating solar power with thermal energy storage. J. Therm. Sci. Eng. Appl. 5 (2013). Available at: http://thermalscienceapplication.asmedigitalcollection.asme.org/ article.aspx? articleid=1690813 doi:10.1115/1.4024143 (accessed August 23, 2015). 
35. Deign J.: Micro-CSP still looking good in Sopogy's wake (2014). Available at: http://social.csptoday.com/markets/micro-csp-stilllooking-good-sopogy's-wake (accessed August 23, 2015).

36. NREL: Saguaro power plant, Arizona, USA. (2006). Available at: http:// www.nrel.gov/csp/solarpaces/project_detail.cfm/projectID=24 (accessed December 23, 2014).

37. Ministry of New and Renewable Energy: Scheffler dish-Operation \& maintenance manual. Available at: http://mnre.gov.in/file-manager/ UserFiles/CST-Manuals/SchefflerDish_E.pdf (accessed July 19, 2015).

38. SHIP: Alanod solar | Solar heat for industrial processes (SHIP) plants database. Available at: http://ship-plants.info/solar-thermalplants/123-alanod-solar-germany?collector_type $=5$ (accessed July 21 , 2015).

39. K. Hennecke: Review of Recent Developments in Solar Heat for Industrial Processes in SolarPACES, 2012, p. 25. Available at: http://elib.dlr.de/ 79849/1/SolarPACES2012_ProcessHeatOverview.pdf (accessed July 18, 2015).

40. CSH India: Steam industrial process heat system using Scheffler dishes at Gajraj dry cleaners, Ahmednagar (2006). Available at: http://cshindia.in/ images/ProcessHeat/GajrajDryCleaners.pdf (accessed February 23, 2015).

41. CSH India: Solar system for process heat by using Arun dishes at M/S. Mahananda Dairy, MIDC, Kalam Road, Latur (2006). Available at: http://cshindia.in/images/ProcessHeat/MahanandaDairy.pdf (accessed February 23, 2015).

42. Clique Solar: Arun dish case studies. Available at: http://www.clique.in/ ARUNSolarBoilerSixCaseStudies.pdf (accessed July 18, 2015).

43. Solarlite-CSP: Solar thermal for fish farming. Available at: http:// solarlite-csp.com/reference/woltow-deutschlandwaerme-fuerfischzuchtanlage/ (accessed February 10, 2015).

44. SHIP: Parabolic trough power plant for a fish farm, Woltow I Solar heat for industrial processes (SHIP) plants database. Available at: http://ship-plants.info/solar-thermal-plants/161-woltow-parabolictrough-power-plant-for-a-fish-farm-germany (accessed July 19, 2015).

45. Australian National University: Solar concentrators | Facilities-Solar thermal group-ANU. Available at: http://stg.anu.edu.au/facilities/ concentrators.php (accessed August 15, 2015).

46. CSH India: Steam is used for process heat by using Arun dishes at M/S. B.G. Chitale, Bhilawadi Station, Sangli, Pune (2009). Available at: http://cshindia.in/images/ProcessHeat/B.G.ChitaleDairy.pdf (accessed February 23, 2015).

47. A. Ebbage: Masdar and NEST partner in TES pilot scheme. (2014). Available at: http://social.csptoday.com/technology/masdar-and-nestpartner-tes-pilot-scheme (accessed December 27, 2014).

48. Mokhtar M., Meyers S.A., Armstrong P.R., and Chiesa M.: Performance analysis of Masdar City's concentrated solar beam-down optical experiment. Sol. Energy Eng. 136, 041007 (2014). Available at: http://solarenergyengineering.asmedigitalcollection.asme.org/Mobile/ article.aspx?articleid=1868645 (accessed July 25, 2015).

49. CSH India: Solar steam for washing engine components by using Arun dishes at M/S. Mahindra Vehicle Manufacturers, Chakan, Pune (2010). Available at: http://cshindia.in/images/ProcessHeat/Mahindra Vehicle.pdf (accessed February 23, 2015).

50. CSH India: Steam laundry system using Scheffler dishes at Clarks hotel, Jaipur, Rajasthan (2008). Available at: http://cshindia.in/ images/ProcessHeat/ClarksHotel.pdf (accessed February 23, 2015).

51. CSH India: Steam laundry system using Arun dishes at ITC hotel New Delhi (2010). Available at: http://cshindia.in/images/ProcessHeat/ ITCArunLaundry.pdf (accessed February 23, 2015).

52. CSH India: A case study of solar concentrators installed at Hotel ITC Maurya, New Delhi. Available at: http://www.cshindia.in/ images/pdf/Casestudy_ITCMaurya_NewDelhi.pdf (accessed July 17, 2015).

53. Ministry of New and Renewable Energy: Solar steam system at hotel ITC Maurya, Delhi (2009). Available at: http://mnre.gov.in/file-manager/
UserFiles/solar_steam_system_for_process_heat.pdf (accessed July 17, 2015).

54. CSH India: Steam laundry system using Scheffler dishes at ITC hotel, New Delhi (2010). Available at: http://cshindia.in/images/ProcessHeat/ ITCSchefflerlaundry.pdf (accessed February 23, 2015).

55. Krüger D., Lichtenthäler N., Dersch J., Schenk H., Hennecke K., Anthrakidis A., Rusack M., Lokurlu A., Saidi K., Walder M., Fischer S., and Wirth H.P.: Solar Steam Supply: Initial Operation of a Plant in ISES solar world congress (Kassel, Germany. Available at: http://elib. dlr.de/71916/1/2011_ISES_P3.pdf, 2011), p. 7. (accessed July 21, 2015).

56. Platforma solar de Almeria: Annual report 2012 (2012). Available at: https://www.psa.es/webesp/techrep/2012/ANNUAL_REPORT_2012.pdf (accessed August 4, 2015).

57. CSH India: Mushroom cultivation using Scheffler dishes at Indian Institute of Horticulture (Bangalore, Karnataka, 2011). Available at: http://cshindia.in/images/ProcessHeat/IndianInstituteofHorticulture.pdf (accessed February 23, 2015).

58. CSP-World: MicroCSP process heat-Tokyo. (2011). Available at: http:// www.csp-world.com/cspworldmap/microcsp-process-heat-tokyo (accessed December 26, 2014).

59. Sopogy: MicroCSP process heat at Tokyo. www.sopogy.org. Available at: http://sopogy.org/projects/index.php?id=60 (accessed December 28, 2014).

60. CSH India: Steam industrial process heat system using Scheffler dishes at B.S. Paper Mill, Ludhiana, Punjab (2011). Available at: http://www. cshindia.in/images/ProcessHeat/B.S.PaperMill.pdf (accessed February 23, 2015).

61. NEP Solar: Process heat-NEP solar. Available at: http://www.nep-solar.com/ projects/process-heat/ (accessed February 10, 2015).

62. Chromasun: Case study: Benson Center (Santa Clara University) (2011). Available at: http://chromasun.com/images/content/resources/ BensonCenterCaseStudy.pdf (accessed February 10, 2015).

63. Green Architecture and Building Report: Energy strategy brings about ROI for Santa Clara University | GAB report. Available at: http://www. gabreport.com/2011/06/energy-strategy-brings-about-roi-for-santa-clarauniversity (accessed July 19, 2015).

64. Durr News: Alternative oven heating. (2013). Available at: http://www. durr-news.com/issues/chinese/detail/news/alternative-oven-heating/ (accessed July 20, 2015).

65. Automotive Manufacturing Solutions: Solar process heat for paintshops | Automotive manufacturing solutions. Available at: http:// www.automotivemanufacturingsolutions.com/process-materials/solarprocess-heat-for-paintshops (accessed July 20, 2015).

66. CSH India: Solar steam for process heat by using Scheffler dishes at M/s. Hindusthan Vidyut Products Ltd, Haryana (2012). Available at: http://www.cshindia.in/images/ProcessHeat/HindusthanVidyut Products.pdf (accessed February 23, 2015).

67. Ministry of New and Renewable Energy: India's quest for solar steam and process heat (2014). Available at: http://www.cliquesolar. com/pressrelease/sun-focus-jan-mar-2014.pdf (accessed July 20, 2015).

68. NEP Solar: NEP solar process heat system "On Sun" at the Tête de Moine Cheese Factory in Saignelégier, Switzerland-NEP SOLAR AG. Available at: http://www.nep-solar.com/news/nep-solar-process-heat-system-sun-tetede-moine-cheese-factory-saignelegier-switzerland/ (accessed July 18, 2015).

69. Ministry of New and Renewable Energy: Sun focus January 2014 | India's quest for solar steam and process heat (2014). Available at: http://mnre. gov.in/file-manager/UserFiles/Sun-Focus_Jan-Mar-2014.pdf (accessed August 10, 2015).

70. Frank E., Mauthner F., and Fischer S.: Solar process heat for production and advanced applications | Overheating prevention and stagnation handling in solar process heat applications (2015). Available at: http://task49.iea-shc.org/Data/Sites/7/frank_iea_shc_task49_ overheatingstagnationreport_approved_v-2-3.pdf (accessed August 10, 2015). 
71. CSH India: Using parabolic trough for phosphating process (2013). Available at: http://www.cshindia.in/images/pdf/SKF.pdf (accessed July 20, 2015).

72. Ministry of New and Renewable Energy: Concentrating solar technologies for process heat, community cooking and cooling applications (2013). Available at: http://www.kredlinfo.in/MysoreWorkshop_MNRE_21032013. pdf (accessed July 20, 2015).

73. Ministry of New and Renewable Energy: SunFocus October 2014 report-CST solutions for industrial requirement (2014). Available at: http://mnre.gov.in/file-manager/UserFiles/Sun-Focus_OctoberDecember-2014.pdf (accessed July 20, 2015).

74. CSH India: Laundry application system using Scheffler dishes at Purple Creation Pvt Ltd., Pune (2012). Available at: http://cshindia.in/ images/ProcessHeat/PurpleCreation.pdf (accessed February 23, 2015).

75. Solar Thermal World, India: Solar system benefits garment factory | Solarthermalworld. Available at: http://www.solarthermalworld.org/ content/india-solar-system-benefits-garment-factory (accessed July 20, 2015).

76. CSP-World: KGDS Narippaiyur desalination CSP plant | CSP World Map | CSP World. (2013). Available at: http://www.csp-world.com/ cspworldmap/kgds-narippaiyur-desalination-csp-plant?utm source $=\mathrm{CSP}+$ World + Newsletter\&utm_campaign $=$ d8adc38de $1-$ 20130603\&utm_medium $=$ email\&utm_term=0_4442a9c781d8adc38de1-32310989 (accessed December 26, 2014).

77. KGDS Renewable Energy Private Limited: Narippaiyur desalination plant. Available at: http://solar.kgisl.com/ (accessed December 26, 2014).

78. Suresh N.: MIT's technology review/India | MIT's magazine on innovation (Cambridge, 2013). Available at: http://solar.kgisl.com/pdf/Jan12_ TRGC.pdf (accessed August 4, 2015).

79. Tamil Nadu Water Supply and Drainage Board: TWAD Board-Narippaiyur desalination plant | BP.MS.NO.69.14.02.2001.pdf (Tamil Nadu Water Supply and Drainage Board, Chennai, 2001). Available at: http://www.twadboard. gov.in/GoBp/Schemes/RuralCwss/BP.MS.NO.69.14.02.2001.pdf (accessed August 4, 2015).

80. Inventive Power: Personal communication to the authors | Angel Mejia (2015). Data received on January 27, 2015.

81. SHIP: Buenavista Greenhouse / Solar heat for industrial processes (SHIP) plants database. Available at: http://ship-plants.info/solarthermal-plants/156-buenavista-greenhouse-mexico (accessed August 10, 2015).

82. Gonzalez B. and Nell C.: BBenergy solar based energy project at Rosherville exceeds design expectations (2013). Available at: http://social.csptoday. com/markets/bbenergy-solar-based-energy-project-rosherville-exceedsdesign-expectations (accessed December 27, 2014).

83. Van Rooy W.L.: Performance evaluation of ESKOM's linear Fresnel concentrating solar thermal pilot plant (IEEE, Cape Town, 2014). Available at: http://ieeexplore.ieee.org/xpl/articleDetails.jsp? arnumber $=6904212$ (accessed July 24, 2015).

84. SHIP: Cremo SA | Solar heat for industrial processes (SHIP) plants database. Available at: http://ship-plants.info/solar-thermal-plants/149cremo-sa-switzerland (accessed July 18, 2015).

85. SHIP: Panoche County desalination | Solar heat for industrial processes (SHIP) plants database. Available at: http://ship-plants.info/solarthermal-plants/151-panoche-county-desalination-united-states (accessed August 10, 2015).

86. SkyFuel: SkyTrough next-generation solar parabolic trough technology. Available at: http://www.skyfuel.com/downloads/brochure/ SkyTroughBrochure.pdf (accessed July 22, 2015).

87. SharperSun: Case study. Available at: http://www.sharpersun.com/ Presentation/SiddharthSurgicalsbyEnergyGuruSharperSunCaseStudy.pdf (accessed July 20, 2015).

88. Ministry of New and Renewable Energy: SunFocus quarterly reportJanuary-March 2015 (2015). Available at: http://mnre.gov.in/filemanager/UserFiles/Sun-Focus_January-March-2015.pdf (accessed July 20, 2015).
89. Megwatt Solutions: Megawatt solutions Pvt. Ltd-Parabolic Dish Technology. Available at: http://megawattsolutions.in/parabolicdishtechnology.html (accessed July 20, 2015).

90. SHIP: Dairy plant (La Doñita) | Solar heat for industrial processes (SHIP) plants database. Available at: http://ship-plants.info/solar-thermalplants/154-dairy-plant-la-donita-mexico? collector_type $=5$ (accessed July 22, 2015).

91. A.T.E. Enterprises Private Ltd: Generate process heat from the sunEnergy efficiency solutions (2014). Available at: http://www.ateindia.com/ component/content/category/32-technical-details/index.php?option= com_content\&view=article\&id=1178:techupdate\&catid=206: greenlink\&Itemid=1476 (accessed July 19, 2015).

92. Soltigua: Industrial process heat in India. Available at: http://www. soltigua.com/wp-content/uploads/2011/05/Case-study-01-India.pdf (accessed July 23, 2015).

93. Soltigua: Soltigua PTMx | A new horizon for solar energy. Available at: http://www.soltigua.com/wp-content/uploads/2014/09/SoltiguaPTMx_ENG.pdf (accessed August 12, 2015).

94. A.Y.T. Al-Zubaydi Solar air conditioning and refrigeration with absorption chillers technology in Australia-An overview on researches and applications. J. Adv. Sci. Eng. Res. 1, 23-41 (2011). Available at: https://www.sign-ific-ance.co.uk/index.php/JASER/article/view/230 (accessed August 14, 2015).

95. Osborne J.: Developing the Australian Solar Cooling Market: Status Update and Lessons from the Solar Thermal Industry in Australian solar cooling conference. Available at: http://www.solarthermalworld.org/sites/gstec/ files/news/file/2013-12-15/jeremy_osborne_status_update_of_the_solar_ thermal_market_paper_1.pdf_.pdf, 2013,p. 11. (accessed August 14, 2015).

96. NEP Solar: Solar cooling projects-NEP solar. Available at: http://www. nep-solar.com/projects/solar-cooling/ (accessed February 10, 2015).

97. Ayadi O., Aprile M., and Motta M.: Solar cooling systems utilizing concentrating solar collectors-An overview. Energy Procedia 30, 875-883 (2012). Available at: http://www.sciencedirect.com/science/article/ pii/S1876610212016153 (accessed August 14, 2015).

98. Ministry of New and Renewable Energy: Undp-gef, solar thermal cooling technologies (2014). Available at: http://mnre.gov.in/file-manager/ UserFiles/Sun-Focus_April-June-2014.pdf (accessed February 10, 2015).

99. C.SH India: Solar system for air conditioning purpose by using Scheffler dishes at Kailash cancer hospital and research center, Muni Seva Ashram. Goraj, Gujarat (2008). Available at: http://cshindia.in/images/Cooling/ Kailash.pdf (accessed February 23, 2015).

100. Sopogy: MicroCSP solar cooling at Sempra. Available at: http://sopogy. org/projects/index.php?id=41 (accessed December 28, 2014).

101. CSH India: Solar system for air conditioning by using Scheffler dishes at m/s. Mahindra Vehicle Manufacturers, Chakan, Pune (2010). Available at: http://www.cshindia.in/images/Cooling/Mahindra3.pdf (accessed February 23, 2015).

102. Millioud A. and Nedeva V.: Concentrating solar process heat (Munich). Available at: http://events.cleantech.com/munich/sites/default/files/ NEP_Solar_Presentation_Cleantech_Forum_Europe.pdf (accessed August 14, 2015).

103. Panchabuta: India achieves major breakthrough in solar thermal cooling system technology Panchabuta | Panchabuta. Available at: http://panchabuta.com/2011/07/01/india-achieves-major-breakthroughin-solar-thermal-cooling-system-technology/ (accessed August 13, 2015).

104. CSH India: Solar system for air conditioning purpose by using Scheffler dishes at CSM hospital Kalwa, Thane, Maharashtra (2011). Available at: http://cshindia.in/images/Cooling/CSM.pdf (accessed February 23, 2015).

105. Sopogy: MicroCSP solar cooling at Masdar. (2011). Available at: http://sopogy.org/projects/index.php?id=40 (accessed December 26, 2014).

106. Sopogy: Fort Bliss solar powered air-conditioning unit. (2011). Available at: http://www.sopogy.org/projects/index.php?id=47 (accessed December 26, 2014). 
107. CSP-World: MicroCSP solar cooling at Fort Bliss. (2011). Available at: http://www.csp-world.com/cspworldmap/microcsp-solar-cooling-fortbliss (accessed December 26, 2014).

108. Charles Smith Associates: Launch of MTN's solar cooling plant. Available at: http://www.csa.co.za/index.php/portfolio/launch-ofmtns-solar-cooling-plant/ (accessed December 27, 2014).

109. CSP-World: MTN CSP cooling plant. Available at: http://www.cspworld.com/cspworldmap/mtn-csp-cooling-plant (accessed December 27, 2014).

110. Wang F., Feng H., Zhao J., Li W., Zhang F., and Liu R.: Performance assessment of solar assisted absorption heat pump system with parabolic trough collectors. Energy Procedia 70, 529-536 (2015). Available at: http://www.sciencedirect.com/science/article/pii/S1876610215002799 (accessed July 24, 2015).

111. CSP Plaza: Tai'an Huaneng built $40 \mathrm{~kW}$ solar ice refrigeration system for cryongenic applications. Available at: http://www.cspplaza.com/ article-2276-1.html (accessed December 28, 2014).

112. Murthy S.: Solar thermal technologies (2011). Available at: http://www. mineco.gob.es/stfls/MICINN/Investigacion/FICHEROS/Presentacion_ participantes_Sevilla/02_Solar_Power_Generation_in_India_SS_ Murthy.pdf (accessed August 14, 2015).

113. Thermax Limited: Sustainable solutions in energy \& environment (2009). Available at: http://www.mercindia.org.in/Presentations_PDF/SessionIV/ Thermax-SolarCooling_GunjanRustagi.pdf (accessed August 14, 2015).

114. Chromasun: Solar thermal case study: Solar cooling system Abu Dhabi distribution company (2011). Available at: http://chromasun.com/images/ content/resources/Abu_Dhabi_V2.pdf (accessed February 10, 2015).

115. Solem Consulting: ADWEA building solar cooling system (2010). Available at: http://chromasun.com/images/content/resources/PIDChromasunADWEASolarCoolingSystemSolem24082010RevB.pdf (accessed January 1, 2015).

116. Soltigua: Solar cooling: case study in the USA (2011). Available at: http://www. soltigua.com/wp-content/uploads/2011/05/Case-study-03-US.pdf (accessed July 23, 2015).

117. Ragheb M.: Solar thermal power, and energy storage (2014). Available at: http://www.solarthermalworld.org/sites/gstec/files/story/2015-04-18/ solar_thermal_power_and_energy_storage_historical_perspective.pdf (accessed July 23, 2015).

118. Egyptian Gazette: Maadi introduces solar energy to the world in 1913 (1913). Available at: http://www.egy.com/maadi/solar-energy.pdf (accessed July 23, 2015).

119. Sun \& Wind Energy: The magazine for renewable energies, "world premiere on the banks of the Nile" (2013). Available at: http://www. sunwindenergy.com/sites/sunwindenergy.com/files/SWE_0613_ 058-061_Solar_thermal_100_years_of_csp_0.pdf (accessed July 23, 2015).

120. Grossman G.: Israeli section of the international solar energy society (Haifa). Available at: http://www.ises.org.il/assets/files/ISESInfo/ IsraelSectionISESfinal.pdf (accessed November 19, 2014).

121. Bronicki L.Y.: Short review of the long history of ORC power systems (2013). Available at: http://www.asme-orc2013.nl/uploads/File/ORC2013KeynotelectureDr.Bronicki.pdf (accessed November 19, 2014).

122. Colonna P., Casati E., Trapp C., Mathijssen T., Larjola J., TurunenSaaresti T., and Uusitalo A.: Organic rankine cycle power systems: From the concept to current technology, applications and an outlook to the future. J. Eng. Gas Turbines Power 137, 1-19 (2015). Available at: http://gasturbinespower.asmedigitalcollection.asme.org/article.aspx? doi=10.1115/1.4029884 (accessed July 23, 2015).

123. Bronicki L.Y.: Personal communication to the authors | Lucien Y. Bronicki (2015). Data received on July 23, 2015.

124. Khaled A.: Thesis, Cairo University, Egypt, 2012. Available at: http://www. uni-kassel.de/eecs/fileadmin/datas/fb16/remena/theses/batch2/ MasterThesis_Ahmad_Yasin.pdf (accessed August 15, 2015).

125. Stine W.B. and Diver R.B.: A compendium of solar dish/Stirling technology (1994). Available at: http://oai.dtic.mil/oai/oai?verb=getRecord\& metadataPrefix $=$ html\&identifier $=$ ADA353041 (accessed August 15, 2015).

126. Pérez M.A.S., Hernández V.R., Granados F.J.G., and Bravo I.L.: Routine Operation of the Envirodish Unit at the Engineering School of the University of Seville in SolarPACES. Available at: https://valerianoruiz.files. wordpress.com/2014/07/14_2006_solarpaces_routineoperation_a7-r1. pdf, 2006, p. 15. (accessed August 14, 2015).

127. Zhiqiang Y. and Xiaowen Z.: Developments of solar thermal in China (2011). Available at: http://solarthermalworld.org/sites/gstec/files/ 03_prof_yin_zhiqiang.pdf (accessed January 27, 2015).

128. Jun W., Yaoming Z., Deyou L., and Su G.: Introduction of the First Solar Power Tower System in China in Proceedings of ISES world congress 2007: Solar energy and human settlement. Available at: http://dx.doi.org/ 10.1007/978-3-540-75997-3_356, 2007,pp. 1738-1742 (accessed July 23, 2015).

129. Wang Z.: Research infrastructure of CSP in China. Available at: http://sfera.sollab.eu/downloads/2nd_presentation.pdf (accessed December 28, 2014).

130. Li X., Wang Z., Yu J., Liu X., Li J., and Song X.: The Power Performance Experiment of Dish-Stirling Solar Thermal Power System in Proceedings of ISES world congress 2007: Solar energy and human settlement, D.Y. Goswami and Y. Zhao, eds.; Springer, Berlin Heidelberg. Available at: http://link.springer.com/chapter/10.1007/978-3-540-75997-3_379), 2007, pp. 1858-1862 (accessed July 23, 2015).

131. Kohlenbach P., Mcevoy S., Stein W., Burton A., Wong K., Lovegrove K., Burgess G., Joe W., and Coventry J.: A New Parabolic Trough Solar Collector in Australian and New Zealand solar energy society (CSIRO, New Castle, Australia). Available at: http://solar.org.au/papers/06papers/ Kohlenbachpaper.pdf, 2006, pp. 1-8 (accessed December 23, 2014).

132. Azizian K., Yaghoubi M., Hesami R., and Mirhadi S.: Shiraz Pilot Solar Thermal Power Plant Design, Construction, Installation and Commissioning Procedure in 7th international conference on heat transfer, fluid mechanics and thermodynamics. Available at: http://www.mehrniro. com/maghalat/1.pdf, 2010, p. 6. (accessed December 27, 2014).

133. CSP-World: Shiraz CSP demonstration plant (Mehr-Niroo project). Available at: http://www.csp-world.com/cspworldmap/shiraz-cspdemonstration-plant-mehr-niroo-project (accessed December 27, 2014).

134. Kim J., Kang Y., Lee S., Yoon H., Yu C., Kim J., and Jo D.: Operation Results of Dish-Stirling Solar Power System. In Proceedings of ISES solar world congress 2007, solar energy and human settlement, Goswami D.Y. and Zhao Y. eds.; Springer, Berlin, Heidelberg. Available at: http://link. springer.com/chapter/10.1007/978-3-540-75997-3_378, 2009, pp. 1854-1857 (accessed July 24, 2015).

135. Sandia National Laboratories, Sandia: Stirling energy systems set new world record for solar-to-grid conversion efficiency-February 12, 2008. Available at: https://share.sandia.gov/news/resources/releases/2008/ solargrid.html (accessed August 15, 2015).

136. Wu Z., Dai W., Man M., and Luo E.: A solar-powered traveling-wave thermoacoustic electricity generator. Sol. Energy 86, 2376-2382 (2012). Available at: http://www.sciencedirect.com/science/article/pii/ S0038092X1200179X (accessed July 24, 2015).

137. Derby R.C. and Lazzara S.P.: Cenicom solar thermal power plant with thermal storage. Available at: http://swezlex.com/pdf/spain_paper.pdf (accessed July 24, 2015).

138. Ministry of New and Renewable Energy: New initiatives. Available at: http://mnre.gov.in/centers/about-sec-2/new-initiatives/ (accessed January 27, 2015).

139. ONGC Energy Center: $9 \mathrm{~kW}_{\mathrm{e}}$ dish Stirling at the solar energy center of MNRE (2004). Available at: http://www.ongcindia.com/wps/wcm/ connect/d98de2a9-2b3b-4f8f-b53e-5a170e4ee1aa/oecst.pdf?MOD= AJPERES\&CACHEID=d98de2a9-2b3b-4f8f-b53e-5a170e4ee1aa (accessed August 4, 2015).

140. Terry Smith: Concentrating solar power technology workshops (2007). Available at: http://www.nrel.gov/csp/troughnet/pdfs/2007/ smith_infinia_dish_stirling.pdf (accessed August 4, 2015).

141. Ramaswamy M.A., Chandrasekaran V.S., Krishnan R., Thirumalai N.C., Suresh N.S., Rao B.S., Dolly S.K., Kanth V.C., and Kumar V.A.: Engineering economic policy assessment of concentrated solar thermal power technologies for India (2012). Available at: http://www.cstep.in/uploads/default/files/ publications/stuff/748b3c48f3e81732eef2c1c67e975112.pdf (accessed August 4, 2015). 
142. Electratherm: Fuel-free power from solar thermal. Available at: http:// electratherm.com/case_studies/middle_east_technical_university_ campus_north_cyprus_turkey/(accessed January 10, 2015).

143. GulfCoast Green Energy: Solar thermal installation on Cyprus Island. Available at: http://gulfcoastgreenenergy.com/waste-heat-to-powerprojects/solar-installation-on-cyprus-island/ (accessed December 20, 2014).

144. CSIRO: Solar thermal foundation project final report: Project results (2014). Available at: http://arena.gov.au/files/2014/06/CSIRO-solar-thermalfoundation-project-final-report-V2.pdf (accessed August 15, 2015).

145. ARENA: Solar air turbine systems | Australian renewable energy agency. Available at: http://arena.gov.au/project/solar-air-turbine-systems/ (accessed August 15, 2015).

146. Solar Energy Research Initiative: Solar energy research initiative (SERI) (2009). Available at: http://www.dst.gov.in/about_us/ar11-12/PDF/ ch4-Solar.pdf (accessed July 21, 2015).

147. Thermax Limited: Thermax India: SolarSolutions: Solar power generation: Distributed solar power solutions. Available at: http://www.thermaxglobal. com/Solar/Solar-Power-Generation/Distributed-Solar-Power-Solutions. aspx (accessed July 21, 2015).

148. Zenith Energy Services Pvt Ltd: CREWA, RSA low carbon services, UNDP. Proceedings of Workshop on Promoting Adoption of Biomass Power Technologies and Identification of Pipeline Projects in Workshop on promoting adoption of biomass power technologies and identification of pipeline projects (UNDP). Available at: http://www.in.undp.org/ content/dam/india/docs/pub-EnE/proceedings-of-workshop-onpromoting-adoption-of-biomass-power-t.pdf, 2013, p. 198 (accessed July 25, 2015).

149. Jang H., Kim T., and Park M.: The First Concentrating Solar Power Project in Korea in SolarPaces conference. Available at: http://cms.solarpaces2012.org/ proceedings/paper/9a438571a3273438828b24a7efc116f, 2012, pp. 1-6 (accessed December 27, 2014).

150. CSP-World: Daegu solar power tower. Available at: http://www. csp-world.com/cspworldmap/daegu-solar-power-tower (accessed December 27, 2014).

151. Clean Technica: Israeli CSP developer AORA solar re-commissions tulip solar power station in Samar. Clean Tech. website (2012). Available at: http://cleantechnica.com/2012/10/31/isreali-csp-developer-aorasolar-re-commissions-tulip-solar-power-station-in-samar/ (accessed December 24, 2014).

152. Israel 21C: Israel's solar-powered tulips. Available at: http://www. israel21c.org/headlines/israels-solar-powered-tulips/ (accessed December 24, 2014).

153. AORA Solar Ltd: AORA Solar's tulip system a hybrid solar thermal solution. Available at: http://www.iitj.ac.in/CSP/material/21dec/aora.pdf (accessed December 24, 2014).

154. AORA Solar Ltd: Tulip ${ }^{\mathrm{TM}}$ DST unit-Features summary. Available at: http://aora-solar.com/datasheet.pdf (accessed December 24, 2014).

155. NREL: Dahan Power Plant (Beijing, China,2012). Available at: http:// www.nrel.gov/csp/solarpaces/project_detail.cfm/projectID $=253$ (accessed December 23, 2014).

156. Wang Z., Li X., Yao Z., and Zhang M.: Concentrating solar power development in China. J. Sol. Energy Eng. 132, 8 (2010). Available at: http://solarenergyengineering.asmedigitalcollection.asme.org/Mobile/ article.aspx?articleid=1458275 (accessed July 24, 2015).

157. CSP Plaza: GOE dish CSP system-Demo Park, Ordos, China. Available at: http://www.cspplaza.com/topic-goe.html\#portal_block_974 (accessed December 28, 2014).

158. Cleanergy: Sunbox for solar parks. Available at: http://cleanergy.com/ wp-content/uploads/2014/06/cleanergy_sunbox_lowres.pdf (accessed August 14, 2015).

159. NREL: Augustin Fresnel 1, Targassonne, France. Available at: http://www. nrel.gov/csp/solarpaces/project_detail.cfm/projectID=222 (accessed December 23, 2014).

160. Itskhokine D., Lecuillier P., Benmarraze S., Rabut Q., and Guillier L.: Augustin Fresnel 1 Project: Design, Construction and Testing of a Linear Fresnel Pilot Plant in the Pyrénées in SolarPACES. Available at: http://www.solareuromed.com/sites/default/files/publications/ ea1334e1b28fd63b_0.pdf, 2012, p. 10 (accessed August 14, 2015).

161. Sandia National Laboratories: National solar thermal test facility. www.nrel.gov (2012). Available at: http://energy.sandia.gov/?page_id=1267 (accessed December 23, 2014).

162. Raush J.R., Chambers T.L., Russo B., and Ritter K.A. III: Demonstration of pilot scale large aperture parabolic trough organic rankine cycle solar thermal power plant in Louisiana. J. Energy Eng. 1, 29-39 (2013). Available at: http://www.scirp.org/journal/PaperInformation.aspx? PaperID=40211\#.VMhfCf54oUq (accessed February 10, 2015).

163. Electratherm: Solar thermal in Louisiana. Available at: http://electratherm. com/case_studies/solar_thermal_in_louisiana/ (accessed January 20, 2015).

164. CSP-World: Archimede-Chiyoda molten salt test loop. Available at: http:// www.csp-world.com/cspworldmap/archimede-chiiyoda-molten-salts-testloop (accessed December 27, 2014).

165. N'Tsoukpoe K.E. and Seshie Y.M.: CSP4AFRICA: Challenges faced during learning by doing a mini-CSP with local mankind and low cost materials (2015). Available at: http://www.researchgate.net/profile/Kokouvi_ NTsoukpoe/publication/262559304_CSP4AFRICA_challenges_faced_ during_learning_by_doing_a_mini-CSP_with_local_mankind_and_low_ cost_materials/links/00b49537f7340f406d000000.pdf (accessed August 4, 2015).

166. Edem N.K.: Experiences, challenges and barriers on solar thermal energy in 2iE and Burkina Faso (2014). Available at: http://www. 2ie-edu.org/assets/Atelier-Cap-Vert-2014.pdf (accessed August 4, 2015).

167. MacKenzie K., Bowers R., Wacker D., Drever R., Jyoti A., and Kearney D.: City of medicine hat concentrating solar thermal demonstration project, Alberta, Canada. Energy Procedia 49, 1792-1799 (2013). Available at: http://www.sciencedirect.com/science/article/pii/S1876610214006444 (accessed December 27, 2014).

168. NREL: City of medicine hat ISCC project. Available at: http://www.nrel.gov/ csp/solarpaces/project_detail.cfm/projectID=278 (accessed December 27, 2014).

169. Electratherm: Electratherm-4400 specification sheet. Available at: https://electratherm-electratherm.netdna-ssl.com/wp-content/ uploads/2015/07/SS-4400-POWER-.pdf (accessed July 26, 2015).

170. FESC: FESC research, education and outreach | Project progress reports (2012). Available at: http://www.floridaenergy.ufl.edu/wp-content/ uploads/USF-Project-Reports-Nov-2012_Part11.pdf (accessed July 26, 2015).

171. Sopogy: Sopogy micro-CSP-Solar thermal, simplified-Products. Available at: http://sopogy.org/products/index.php?id=31 (accessed July 26, 2015).

172. HelioFocus: HelioFocus Tech datasheet (2007). Available at: http://www. heliofocus.com/wp-content/uploads/13100102_HelioFocus-TechDatasheet.pdf (accessed December 27, 2014).

173. HelioFocus: Heliofocus | STARDUST project Israel. Available at: http:// www.heliofocus.com/1564-2/ (accessed July 26, 2015).

174. Energias Renovables: HelioBooster CSP system to increase output at fossil fuel plant. Available at: http://www.energias-renovables.com/ articulo/heliobooster-csp-system-to-increase-output-at (accessed July 26, 2015).

175. American Inventor Uses Egypt's Sun for Power: Appliance concentrates the heat rays and produces steam. New York Times (1916). Available at: http://query.nytimes.com/mem/archive-free/pdf?res= 990CE7DF1E3FE233A25751C0A9619C946796D6CF (accessed August 23, 2015).

176. Orosz M.S., Mueller A., Sylvain Q., and Hemond H.: Small Scale Solar ORC System for Distributed Power in SolarPACES. Available at: http://www.scopus.com/inward/record.url?eid=2-s2.0-84873835908\& partnerID=tZOtx3y1, 2009, vol. 2, pp. 1042-1048 (accessed March 21, 2014).

177. Solarlite-CSP: Tri-generation facility at Thailand. Available at: http:// solarlite-csp.com/reference/tse-2-suphanburi-provinz-thailand/ (accessed February 10, 2015). 
178. Kruger D., Kruger J., Sukchai S., Breitzke P., Rahbani M., Schenk H., Hempel S., Caf S., Karthikeyan R., and Hennecke K.: Solar Cogeneration with Parabolic Trough Collectors in TRESERT Phitanulok, ThailandTriGeneration (electricity, heat, refrigeration) in EuroSun 2006. Available at: http://elib.dlr.de/78127/1/2012_SolarPACES_Tresert.pdf, 2006,p. 5 (accessed August 4, 2015).

179. Solarlite-CSP: Solar trough station in Chonburi, Thailand. Available at: http://solarlite-csp.com/reference/proof-of-concept-parabolrinnenanlagein-chonburi-thailand/ (accessed February 10, 2015).

180. Krueger J., Rakwichian W., Sukchai S., and Pongtornkulpanich A.: Small solar trough power plant in Thailand. Int. J. Renew. Energy. 7, 13 (2012). Available at: http://www.sert.nu.ac.th/IIRE/FP_V7N1(3).pdf (accessed August 4, 2015).

181. Price H., Lüpfert E., Kearney D., Zarza E., Cohen G., Gee R., and Mahoney R.: Advances in parabolic trough solar power technology. J. Sol. Energy Eng. 124, 109-125 (2002). Available at: http://solarenergyengineering. asmedigitalcollection.asme.org/article.aspx?articleid=1456429 (accessed August 23, 2015).

182. Burkholder F. and Kutscher C.: Heat loss testing of Schott's 2008 PTR70 parabolic trough receiver (2009). Available at: http://www.nrel.gov/docs/ fy09osti/45633.pdf (accessed September 9, 2015).

183. Chen J., Yan Z., Lin G., and Andresen B.: On the Curzon-Ahlborn efficiency and its connection with the efficiencies of real heat engines. Energy Convers. Manag. 42, 173-181 (2001). Available at: http://www. sciencedirect.com/science/article/pii/S0196890400000558 (accessed September 9, 2015).

184. Office of Energy Efficiency \& Renewable Energy: Thermal storage R\&D for CSP systems | Department of energy. Available at: http://energy.gov/ eere/sunshot/thermal-storage-rd-csp-systems (accessed September 9 , 2015).

185. IEA-ETSAP/IRENA: Thermal energy storage | Technology brief (2013). Available at: https://www.irena.org/DocumentDownloads/Publications/ IRENA-ETSAPTechBriefE17ThermalEnergyStorage.pdf (accessed August 23, 2015).

186. Turchi C.: Parabolic trough reference plant for cost modeling with the solar advisor model (SAM) (2010). Available at: http://www.nrel.gov/docs/ fy10osti/47605.pdf (accessed August 23, 2015).

187. Mitterhofer M. and Orosz M.: Dynamic Simulation and Optimization of a Micro-CSP Power Plant in ASME 2015 power and energy conversion conference, San Diego. Available at: https://www.researchgate.net/ profile/Matthew_Orosz2/publication/281111698_DYNAMIC_ SIMULATION_AND_OPTIMIZATION_OF_AN_EXPERIMENTAL_ MICRO-CSP_POWER_PLANT/links/55d6349908aeb38e8a83ed51.pdf (accessed September 12, 2015).

188. Orosz M. and Mueller A.: Dynamic Simulation of Performance and Cost of Hybrid PV-CSP-LPG Generator Micro Grids with Applications to Remote Communities in Developing Countries in ASME 2015 power and energy conversion conference, San Diego. Available at: https://www.researchgate. net/profile/Matthew_Orosz2/publication/281111599_DYNAMIC_ SIMULATION_OF_PERFORMANCE_AND_COST_OF_HYBRID_ PV-CSP-LPG_GENERATOR_MICRO_GRIDS_WITH_APPLICATIONS_ TO_REMOTE_COMMUNITIES_IN_DEVELOPING_COUNTRIES/ links/55d6332e08ae9d65948bcc8e (accessed September 12, 2015).

189. African Development Bank Group: The high cost of electricity generation in Africa-African development bank. Available at: http://www.afdb.org/ en/blogs/afdb-championing-inclusive-growth-across-africa/post/ the-high-cost-of-electricity-generation-in-africa-11496/ (accessed September 9, 2015).

190. Aggarwal V., Fahey A., Freymiller H.S., Li S., Huang C.C., Moilanen S., Onda C., Ratledge N., Speirs S., and Wong J.: Rural energy alternatives in India: Opportunities in financing and community engagement for renewable energy microgrid projects (2014). Available at: https://wws.princeton.edu/ sites/default/files/content/591fRuralEnergyAlternativesinIndia.pdf (accessed September 12, 2015)

191. The World Bank: World Bank database: Population density (people/sq. km of land area). Available at: http://data.worldbank.org/indicator/EN.POP. DNST (accessed May 15, 2015).
192. The World Bank: World Bank Database: Energy use (kg of oil equivalent per capita). Available at: http://data.worldbank.org/indicator/EG.USE. PCAP.KG.OE (accessed May 15, 2015).

193. NEP Solar: Desalination-NEP Solar. Available at: http://www.nep-solar. com/projects/desalination/ (accessed February 20, 2015).

194. Mason A.: SkyFuel's parabolic trough powers thermal desalination (Colorado, 2014). Available at: http://www.skyfuel.com/downloads/press_releases/ PressReleaseATSI(AMason)2014.pdf (accessed July 22, 2015).

195. Stine W. and Geyer M.: Power from the Sun-Chapter 16: Solar Thermal Projects in Solar energy system and design, John Wiley. Available at: http://www.powerfromthesun.net/Book/chapter16/chapter16.html, 1985, p. 552 (accessed August 23, 2015).

196. Solar pump aids irrigation (1978). Available at: https://books.google. com/books?id=oM8DAAAAMBAJ\&pg=PA96\&lpg=PA96\&dq=Solar ${ }^{+}$ pump+aids+irrigation + popular + mechanics \&source=bl\&ots $=$ EIJ KOc-LGl\&sig=YdJFvc-q8FfGI_27cpSr9bCF7L8\&hl=en\&sa=X\&ved= 0ahUKEwi16d3KoazKAhXEJR4KHUZMC-EQ6AEIHDAA\# ${ }_{\mathrm{v}}=$ onepage\& $\mathrm{q}=$ Solarpumpaidsi (accessed August 23, 2015).

197. Talbert S.G., Fischer R.D., Alexander G., Frieling D.H., and Eibling J.A.: Development of a $37 \mathrm{~kW}$ Solar-Powered Irrigation System in Proceedings of ISES solar world congress (Pergamon Press, New Delhi). Available at: https://www.researchgate.net/publication/253696138_The_ development_of_a_37_kW_solar-powered_irrigation_system, 1978), vol. December, pp. 2138-2142 (accessed August 23, 2015).

198. Kiceniuk T.: Development of an organic Rankine-Cycle power module for a small community solar thermal power experiment (Pasadena, California, 1985). Available at: http://ntrs.nasa.gov/archive/nasa/casi.ntrs.nasa. gov/19850016212.pdf (accessed August 23, 2015).

199. Mills D.: Solar thermal electricity in Australia (2013). Available at: http://solar.org.au/wp-content/uploads/2013/07/halfcentury/9.Mills.pdf (accessed August 23, 2015).

200. Stine W. and Geyer M.: Power from the Sun-Chapter 12: Power Cycles for Electricity Generation in Solar energy system and design, John Wiley. Available at: http://www.powerfromthesun.net/Book/chapter12/ chapter12.html, 1985, p. 552 (accessed August 23, 2015).

201. Larson D.L.: A $150 \mathrm{~kW}$ solar power plant to drive irrigation pumps (1983). Available at: http://arizona.openrepository.com/arizona/handle/ 10150/219356 (accessed August 23, 2015).

202. Fenton D.L., Abernathy G.H., Krivokapich G.A., and Otts J.V.: Operation and evaluation of the Willard solar thermal power irrigation system. Sol. Energy 32, 735-751 (1984). Available at: http://www.sciencedirect. com/science/article/pii/0038092X84902482 (accessed August 23, 2015).

203. Boy-Marcotte J.L., Dancette M., Bliaux J., Bacconnet E., and Malherbe J.: Construction of a $100 \mathrm{~kW}$ solar thermal-electric experimental plant. J. Sol. Energy Eng. Trans. ASME 107, 196-201 (1985). Available at: http://solarenergyengineering.asmedigitalcollection.asme.org/article. aspx?articleid=1454428 (accessed August 23, 2015).

204. Kane M., Larrain D., Favrat D., and Allani Y.: Small hybrid solar power system. Energy 28, 1427-1443 (2003). Available at: http://infoscience. epfl.ch/record/53476/files/LENI-2001-010.pdf (accessed August 23, 2015).

205. Galvez J.B.: Powersol: Mechanical power generation based on solar thermodynamic engines-Final report (2010). Available at: http:// cordis.europa.eu/docs/publications/1245/124584721-6_en.pdf (accessed August 23, 2015).

206. Infinia, ESMAP: Infinia | Distributed solar power. Available at: https://www.esmap.org/sites/esmap.org/files/ESMAP_IFC_RE_ Training_INFINIA_Letendre.pdf (accessed August 4, 2015).

207. Daccord R. and Rieu V.: A $10 \mathrm{~kW}$ solar power plant for rural electrification. SolarPACES (2012). Available at: http://www.asme-orc2013.nl/mobview/ presentation/4204 (accessed August 23, 2015).

208. NREL: NREL: Concentrating solar power projects-Rende-CSP plant. Available at: http://www.nrel.gov/csp/solarpaces/project_detail.cfm/ projectID=4288 (accessed August 15, 2015).

209. Falck Renewables: Falck Renewables: The first hybrid thermodynamic solar concentration and biomass plant started up in Rende in Calabria (2014). Available at: http://www.falckrenewables.eu/ /media/Files/F/ 
Falck-Renewables-Bm2012/pdfs/press-release/2014/FKRPressrelease _ SolareTermodinamico.pdf (accessed August 14, 2015).

210. HelioFocus: Project Stardust. Available at: http://www.heliofocus.com/ stardust-project-new/ (accessed December 27, 2014).

211. Schmidt G., Zewen H., and Moustafa S.: A solar farm with parabolic dishes (Kuwaiti-German project). Electr. Power Syst. Res. 3, 65-76 (1980). Available at: http://www.sciencedirect.com/science/article/pii/ 0378779680900231 (accessed August 23, 2015).

212. Moustafa S., Hoefler W., El-Mansy H., Kamal A., Jarrar D., Hoppman H., and Zewen H.: Design specifications and application of a $100 \mathrm{~kW}_{\mathrm{e}}\left(700 \mathrm{~kW}_{\text {th }}\right)$ cogeneration solar power plant. Sol. Energy 32, 263-269 (1984). Available at: https://www.researchgate.net/publication/223248348_Design_ specifications_and_application_of_a100_kWc700_kWth_cogeneration_ solar_power_plant (accessed August 23, 2015).

213. Moustafa S., El-Mansy H., Elimam A., and Zewen H.: Operational strategies for Kuwait's $100 \mathrm{~kW}_{\mathrm{e}} / 0.7 \mathrm{MW}_{\text {th }}$ solar power plant. Sol. Energy 34, 231-238 (1985). Available at: http://www.sciencedirect.com/science/ article/pii/0038092X8590060X (accessed August 23, 2015).

214. Saitoh T.S. and Hoshi A.: Proposed solar Rankine Cycle System with Phase Change Steam Accumulator and CPC Solar Collector in 37th Intersociety Energy Conversion Engineering conference. Available at: http:// ieeexplore.ieee.org/xpls/abs_all.jsp?arnumber=1392137\&tag=1, 2002, pp. 725-730 (accessed December 23, 2014).

215. European Solar Thermal Industry Federation: Solar assisted cooling | State of the art (2006). Available at: http://www.estif.org/fileadmin/estif/ content/policies/downloads/D23-solar-assisted-cooling.pdf (accessed August 15, 2015).

216. WWF-India, CEEW: Renewables beyond electricity | Solar air conditioning \& desalination in India. Available at: http://awsassets.wwfindia.org/ downloads/re__report_web.pdf (accessed August 15, 2015).

217. Antonio M.D., Maxwell J., Rigos W., and Pedrick G.: Post-Installation Performance Characteristics of a Solar-Driven System for Industrial Dehumidification and Steam Generation in ACEEE summer study on energy efficiency in industry. Available at: http://aceee.org/files/ proceedings/2011/data/papers/0085-000104.pdf, 2011, pp. 45-56 (accessed August 15, 2015).
218. Maxwell J.B., Antonio M.D., Henkel E.T., May K., and Creamer K.: A Solar Thermal System for Industrial Dehumidification and Steam Generation The History of Solar Thermal Cooling in the United States in ACEEE summer study on energy efficiency in industry. Available at: http://aceee.org/files/ proceedings/2009/data/papers/3_1.pdf, 2009,pp. 80-90 (accessed August 15, 2015).

219. Chromasun: Case study: Crow Canyon Medical Center combination solar cooling \& heating system (2013). Available at: http://chromasun. com/images/content/CCMCCaseStudy_jan30,2013.pdf (accessed February 10, 2015).

220. Chromasun: Hawaii Hotel CHW and DHW Case Study in Solar heating and cooling conference. Available at: http://task48.iea-shc.org/Data/ Sites/6/documents/events/sch2012/Chromasun.pdf, 2012, p. 35 (accessed August 4, 2015).

221. India-One: India-One solar thermal power plant: Power generation that makes a difference. Available at: http://www.india-one.net/images/ India-One150dpi.pdf (accessed December 27, 2014).

222. India-One: About the project: India One solar thermal power plant. Available at: http://india-one.net/abouttheproject.html (accessed December 27, 2014).

223. World Renewal Spiritual Trust, Executive Summary: India One-1 MW solar thermal power plant. Available at: http://www.india-one.net/ images/ExecutiveSummary.pdf (accessed June 18, 2015).

224. Qu M., Masson S., and Archer D.: Solar absorption cooling/heating system for the intelligent workplace IW solar cooling/heating system (2006). Available at: http://www.cmu.edu/iwess/workshops/IWESS_Solar_ Oct06.pdf (accessed August 15, 2015).

225. Qu M., Yin H., and Archer D.H.: A solar thermal cooling and heating system for a building: Experimental and model based performance analysis and design. Sol. Energy 84, 166-182 (2010). Available at: http://www. sciencedirect.com/science/article/pii/S0038092X09002424 (accessed July 24, 2015).

226. Barlev D., Vidu R., and Stroeve P.: Innovation in concentrated solar power. Sol. Energy Mater. Sol. Cells 95, 2703-2725 (2011). Available at: http://www. sciencedirect.com/science/article/pii/S0927024811002777 (accessed July 10, 2014). 


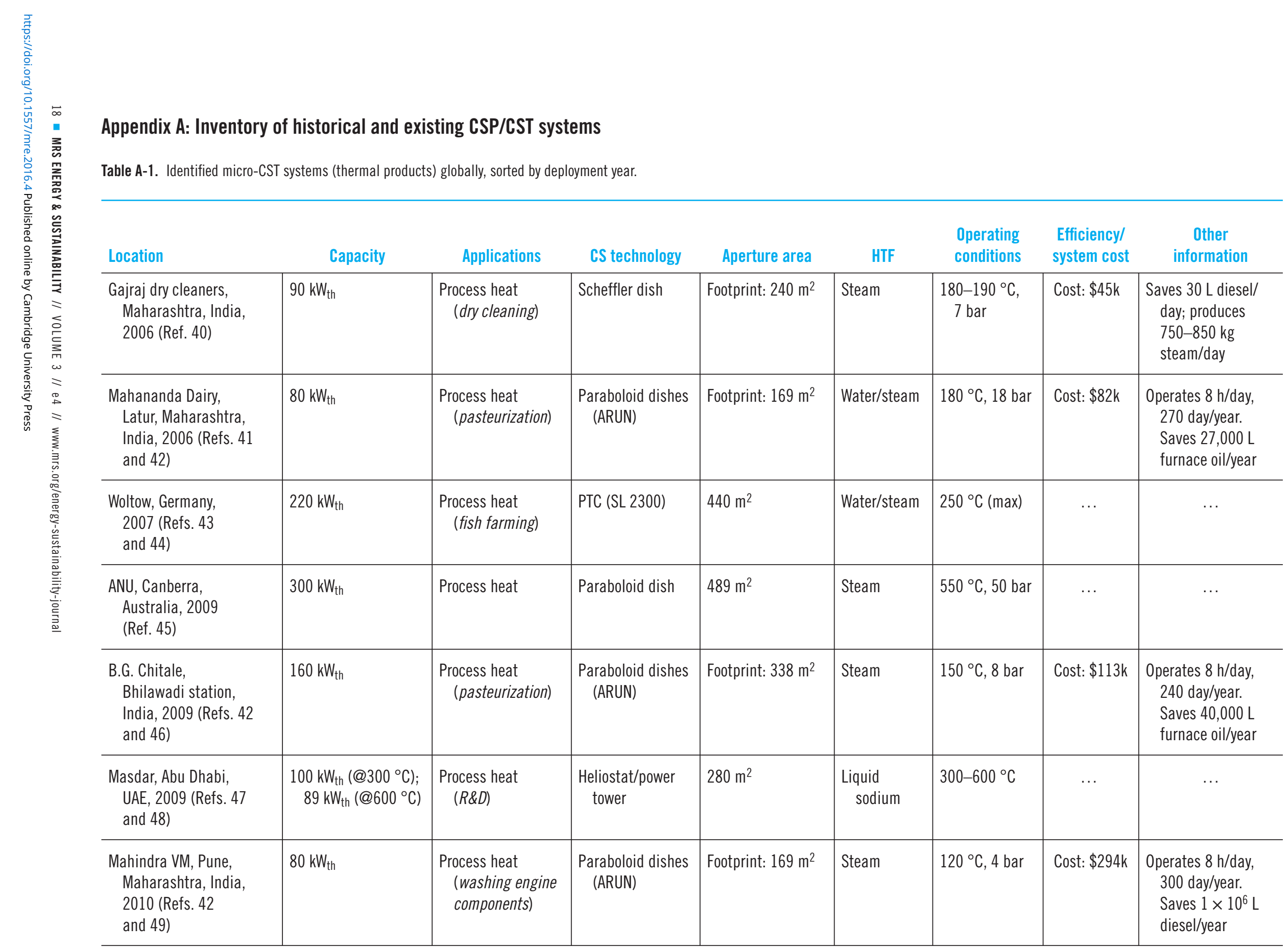


Table A-1. Continued

\begin{tabular}{|c|c|c|c|c|c|c|c|c|}
\hline Location & Capacity & Applications & CS technology & Aperture area & HTF & $\begin{array}{l}\text { Operating } \\
\text { conditions }\end{array}$ & $\begin{array}{l}\text { Efficiency/ } \\
\text { system cost }\end{array}$ & $\begin{array}{c}\text { Other } \\
\text { information }\end{array}$ \\
\hline $\begin{array}{l}\text { Clarks Hotel, Jaipur, } \\
\text { Rajasthan, India, } \\
2010 \text { (Ref. 50) }\end{array}$ & $28 \mathrm{~kW}_{\mathrm{th}^{\mathrm{a}}}{ }^{\mathrm{a}}$ & $\begin{array}{l}\text { Process heat } \\
\text { (laundry \& } \\
\text { chlorifier) }\end{array}$ & Scheffler dish & Footprint: $80 \mathrm{~m}^{2}$ & Steam & $2-2.5 \mathrm{bar}$ & Cost: $\$ 26 \mathrm{k}$ & $\begin{array}{l}\text { Operates } 7 \text { h/day. } \\
\text { Saves } 3200 \mathrm{~L} \\
\text { diesel/year }\end{array}$ \\
\hline $\begin{array}{l}\text { Heavy water plant, } \\
\text { Kota, Rajasthan, } \\
\text { India, } 2010 \text { (Ref. 42) }\end{array}$ & $320 \mathrm{~kW}_{\text {th }}$ & $\begin{array}{l}\text { Process } \\
\text { heat (steam } \\
\text { generation) }\end{array}$ & $\begin{array}{l}\text { Paraboloid dishes } \\
\text { (ARUN) }\end{array}$ & Footprint: $676 \mathrm{~m}^{2}$ & Steam & 6 bar & $\cdots$ & $200 \mathrm{~kg}$ steam $/ \mathrm{h}$ \\
\hline $\begin{array}{l}\text { ITC Maurya Hotel, } \\
\text { New Delhi, India, } 2010 \\
\text { (Refs. } 51 \text { and 52) }\end{array}$ & 160 kW th (Ref. 53) & $\begin{array}{l}\text { Process heat } \\
\text { (laundry) }\end{array}$ & $\begin{array}{l}\text { Paraboloid dishes } \\
\text { (ARUN) }\end{array}$ & Footprint: $338 \mathrm{~m}^{2}$ & Steam & $175^{\circ} \mathrm{C}, 8$ bar & Cost: $\$ 160 k$ & Operates 7 h/day \\
\hline $\begin{array}{l}\text { ITC Maurya Hotel, } \\
\text { New Delhi, India, } 2010 \\
\text { (Refs. } 52 \text { and 54) }\end{array}$ & $44 \mathrm{~kW}_{\mathrm{th}^{\mathrm{a}}}{ }^{\mathrm{a}}$ & $\begin{array}{l}\text { Process heat } \\
\text { (laundry) }\end{array}$ & Scheffler dish & Footprint: $128 \mathrm{~m}^{2}$ & Steam & $\begin{array}{c}100-120^{\circ} \mathrm{C} \\
4-8 \text { bar }\end{array}$ & Cost: $\$ 55 \mathrm{k}$ & 0perates $7 \mathrm{~h} /$ day \\
\hline $\begin{array}{l}\text { Alanod solar, Ennepetal, } \\
\text { Germany, } 2010 \\
\text { (Refs. } 38 \text { and 55) }\end{array}$ & $76 \mathrm{~kW}_{\mathrm{th}^{\mathrm{b}}}$ & $\begin{array}{l}\text { Process heat } \\
\text { (aluminum } \\
\text { processing) }\end{array}$ & PTC & Gross: $108 \mathrm{~m}^{2}$ & Steam & $143^{\circ} \mathrm{C}, 4$ bar & $\ldots$ & $\ldots$ \\
\hline $\begin{array}{l}\text { PSA MED plant, Almeria, } \\
\text { Spain, } 2010 \text { (Refs. } 56 \\
\text { and 193) }\end{array}$ & $125 \mathrm{~kW}_{\text {th }}$ & $\begin{array}{l}\text { Process heat } \\
\text { (desalination) }\end{array}$ & PTC (PT 1200) & $230 \mathrm{~m}^{2}$ & Thermal oil & $400^{\circ} \mathrm{C}$ & $\cdots$ & MED desalination \\
\hline $\begin{array}{l}\text { IIH, Bangalore, Karnataka, } \\
\text { India, } 2011 \text { (Ref. 57) }\end{array}$ & $14 \mathrm{~kW}_{\mathrm{th}^{\mathrm{a}}}$ & $\begin{array}{l}\text { Process heat } \\
\text { (mushroom } \\
\text { cultivation) }\end{array}$ & Scheffler dish & Footprint: $42 \mathrm{~m}^{2}$ & Steam & $\begin{array}{l}85-100^{\circ} \mathrm{C} \\
4-6 \text { bar }\end{array}$ & Cost: $\$ 6 \mathrm{k}$ & $\begin{array}{l}\text { Operates } 4 \text { h/day, } \\
60 \text { day/year. Saves } \\
1.4 \mathrm{MW} \text { h/year }\end{array}$ \\
\hline $\begin{array}{l}\text { Tokyo, Japan, } 2011 \\
\text { (Refs. } 58 \text { and 59) }\end{array}$ & $100 \mathrm{~kW}_{\text {th }}$ & Process heat & PTC (SopoNova) & Footprint: $2023 \mathrm{~m}^{2}$ & $\begin{array}{l}\text { Xceltherm } \\
600\end{array}$ & $176^{\circ} \mathrm{C}$ & $\ldots$ & $\cdots$ \\
\hline
\end{tabular}




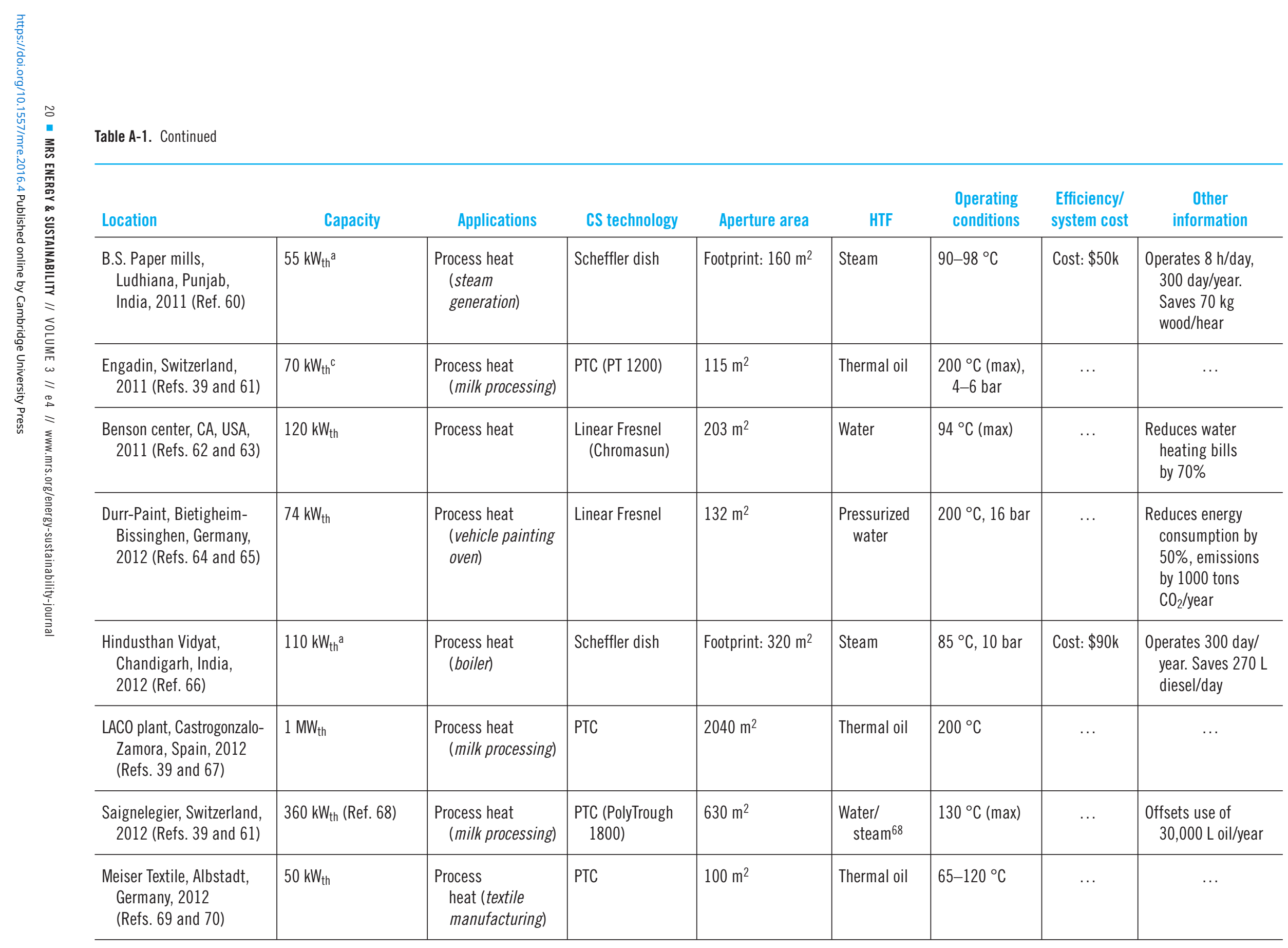


Table A-1. Continued

\begin{tabular}{|c|c|c|c|c|c|c|c|c|}
\hline Location & Capacity & Applications & CS technology & Aperture area & HTF & $\begin{array}{l}\text { Operating } \\
\text { conditions }\end{array}$ & $\begin{array}{l}\text { Efficiency/ } \\
\text { system cost }\end{array}$ & $\begin{array}{c}\text { Other } \\
\text { information }\end{array}$ \\
\hline $\begin{array}{l}\text { SKF Technologies, Mysore, } \\
\text { Karnataka, India, } 2013 \\
\text { (Refs. 71-73) }\end{array}$ & $64 \mathrm{~kW}_{\text {th }}$ & $\begin{array}{l}\text { Process } \\
\text { heat (metal } \\
\text { phosphating) }\end{array}$ & PTC & $256 \mathrm{~m}^{2}$ & $\begin{array}{r}\text { Pressurized } \\
\text { hot water }\end{array}$ & $130^{\circ} \mathrm{C}$ & $\cdots$ & $\begin{array}{l}\text { Offsets 12,000 L } \\
\text { diesel/year }\end{array}$ \\
\hline $\begin{array}{l}\text { Purple creations Ltd, } \\
\text { Maharashtra, India, } \\
2013 \text { (Refs. } 74 \\
\text { and 75) }\end{array}$ & $165 \mathrm{~kW}_{\text {th }^{\mathrm{a}}}$ & $\begin{array}{l}\text { Process heat } \\
\text { (laundry) }\end{array}$ & Scheffler dish & Footprint: $480 \mathrm{~m}^{2}$ & Steam & $160^{\circ} \mathrm{C}, 6$ bar & Cost: $\$ 102 \mathrm{k}$ & $\begin{array}{l}\text { Operates } 7 \text { h/day. } \\
\text { Saves } 4500 \text { kg } \\
\text { LPG/day }\end{array}$ \\
\hline $\begin{array}{l}\text { Narippaiyur, Tamil Nadu, } \\
\text { India, } 2013 \text { (Refs. } \\
\text { 76-79) }\end{array}$ & $480 \mathrm{~kW}_{\text {th }}$ & $\begin{array}{l}\text { Process heat } \\
\text { (desalination) }\end{array}$ & Linear Fresnel & $1404 \mathrm{~m}^{2}$ & $\begin{array}{l}\text { HTF: water/ } \\
\text { steam }\end{array}$ & $257^{\circ} \mathrm{C}, 45 \mathrm{bar}$ & $\ldots$ & $6000 \mathrm{~L} / \mathrm{h}$ output \\
\hline $\begin{array}{l}\text { COVBARS, Durango, } \\
\text { Méxic0, } 2013 \text { (Ref. 80) }\end{array}$ & $61 \mathrm{~kW}_{\text {th }}$ & $\begin{array}{l}\text { Process heat } \\
\text { (boiler make-up) }\end{array}$ & PTC & $198 \mathrm{~m}^{2}$ & Water & $95^{\circ} \mathrm{C}$ & $\ldots$ & $\ldots$ \\
\hline $\begin{array}{l}\text { Buena Vista Greenhouse, } \\
\text { Jalisco, Mexico, } 2013 \\
\text { (Ref. 81) }\end{array}$ & $36 \mathrm{~kW}_{\text {th }}$ & $\begin{array}{l}\text { Process heat } \\
\text { (space heating) }\end{array}$ & PTC (PT110) & $66 \mathrm{~m}^{2}$ & Glycol & $80^{\circ} \mathrm{C}(\max )$ & $\ldots$ & $\begin{array}{l}2500 \mathrm{~L} \text { hot water } \\
\text { storage }\end{array}$ \\
\hline $\begin{array}{l}\text { Quesera Matatlán, } \\
\text { Jalisco, México, } 2013 \\
\text { (Ref. 80) }\end{array}$ & $24 \mathrm{~kW}_{\text {th }}$ & $\begin{array}{l}\text { Process heat } \\
\text { (boiler make-up) }\end{array}$ & PTC & $60 \mathrm{~m}^{2}$ & Water & $95^{\circ} \mathrm{C}$ & $\ldots$ & $\ldots$ \\
\hline $\begin{array}{l}\text { Rosherville, South Africa, } \\
2013 \text { (Refs. } 82 \text { and 83) }\end{array}$ & $150 \mathrm{~kW}_{\text {th }}$ & $\begin{array}{l}\text { Process heat } \\
\qquad(R \& D)\end{array}$ & Linear Fresnel & $234 \mathrm{~m}^{2}$ & Water & $250^{\circ} \mathrm{C}, 40 \mathrm{bar}$ & $\begin{array}{l}\text { Solar-to- } \\
\text { thermal } \\
\text { eff: } 60 \%\end{array}$ & $\begin{array}{l}\text { Annual capacity } \\
\text { factor: } 10 \%\end{array}$ \\
\hline $\begin{array}{l}\text { Cremo, Fribourg, } \\
\text { Switzerland, } 2013 \\
\text { (Refs. } 61 \text { and } 84 \text { ) }\end{array}$ & $330 \mathrm{~kW}_{\text {th }}$ & $\begin{array}{l}\text { Process heat } \\
\text { (milk processing) }\end{array}$ & $\begin{array}{l}\text { PTC (PolyTrough } \\
\text { 1800) }\end{array}$ & $580 \mathrm{~m}^{2}$ & Water & $150^{\circ} \mathrm{C}(\max )$ & $\ldots$ & $\begin{array}{l}\text { Offsets use of } \\
25,000 \text { L oil/year }\end{array}$ \\
\hline
\end{tabular}




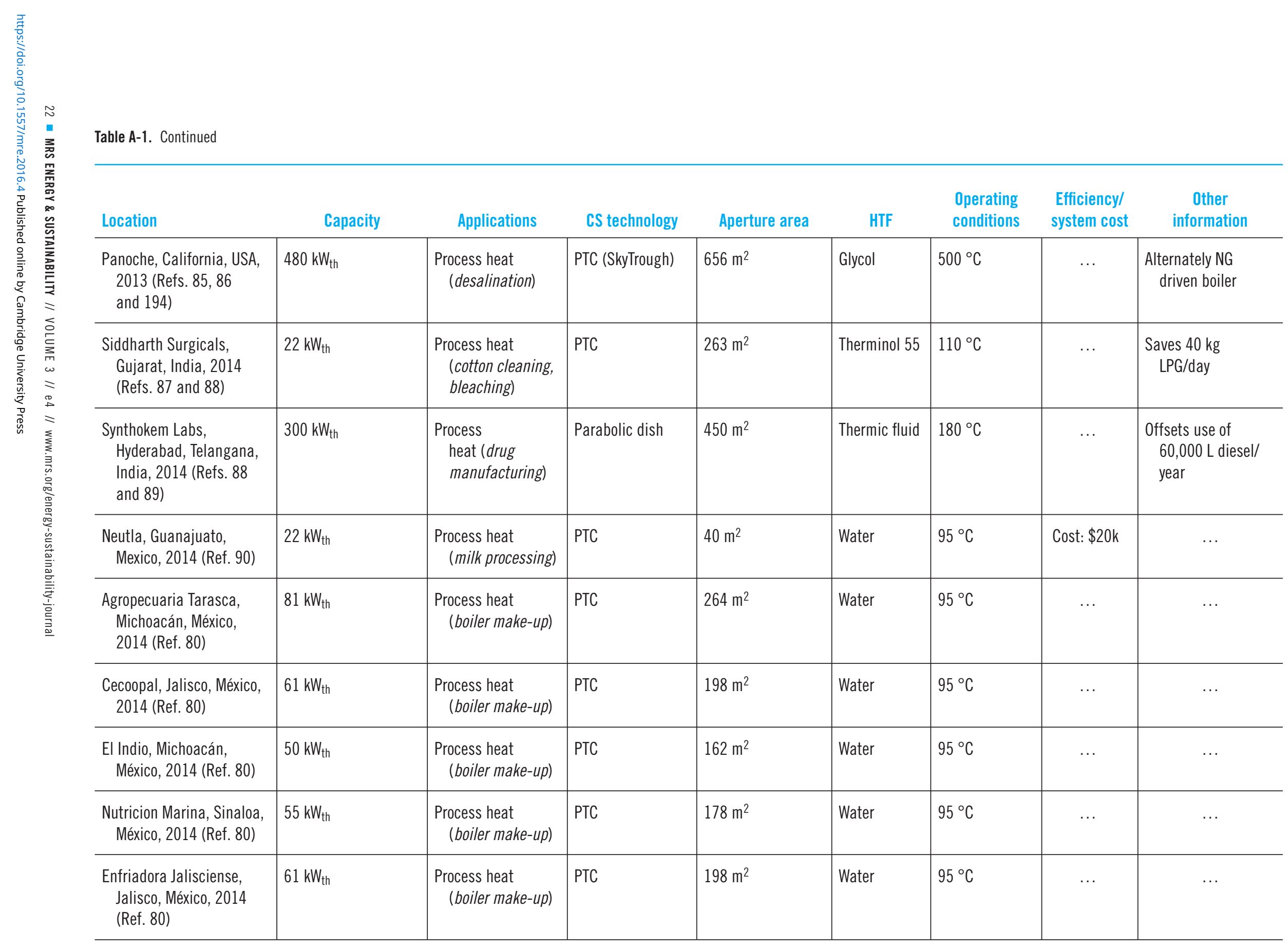


Table A-1. Continued

\begin{tabular}{|c|c|c|c|c|c|c|c|c|}
\hline Location & Capacity & Applications & CS technology & Aperture area & HTF & $\begin{array}{l}\text { Operating } \\
\text { conditions }\end{array}$ & $\begin{array}{l}\text { Efficiency/ } \\
\text { system cost }\end{array}$ & $\begin{array}{c}\text { Other } \\
\text { information }\end{array}$ \\
\hline $\begin{array}{l}\text { Nestle, Chiapas, México, } \\
2015 \text { (Ref. 80) }\end{array}$ & $67 \mathrm{~kW}_{\text {th }}$ & Process heat & PTC & $218 \mathrm{~m}^{2}$ & Water & $90^{\circ} \mathrm{C}$ & $\ldots$ & $\ldots$ \\
\hline $\begin{array}{l}\text { Snow White Laundry, } \\
\text { Maharashtra, India } \\
\text { (Ref. 91) }\end{array}$ & $3 \mathrm{~kW}_{\text {th }}$ & $\begin{array}{l}\text { Process heat } \\
\text { (laundry) }\end{array}$ & $\begin{array}{l}\text { Paraboloid } \\
\text { dish }\end{array}$ & $25 \mathrm{~m}^{2}$ & Water/steam & $\ldots$ & $\ldots$ & $\begin{array}{l}\text { Savings in fuel: } \\
7 \text { kg LPG/day, } \\
60 \text { kg wood/day }\end{array}$ \\
\hline $\begin{array}{l}\text { Textile industry, Tamil } \\
\text { Nadu, India (Refs. } 92 \\
\text { and 93) }\end{array}$ & $600 \mathrm{~kW}_{\text {th }}$ & Process heat & PTC & $1080 \mathrm{~m}^{2}$ & Thermal oil & $\begin{array}{l}135^{\circ} \mathrm{C} \\
5-6 \text { bar }\end{array}$ & $\ldots$ & $\begin{array}{l}\text { Steam production } \\
\text { in heat exchanger }\end{array}$ \\
\hline
\end{tabular}

a Implies capacity $\left(\mathrm{kW}_{\text {th }}\right)$ calculated from reported Scheffler specifications of $5.5 \mathrm{~kW}_{\text {th }} / \mathrm{dish}^{37}$

${ }^{b}$ Calculated from Ref. 38.

c Implies capacity $\left(\mathrm{kW}_{\text {th }}\right)$ reported in Ref. 39.

Table A-2. Identified micro-CST systems (cooling applications) globally, sorted by deployment yeara

\begin{tabular}{|c|c|c|c|c|c|c|c|c|}
\hline Location & Capacity & Applications & CSP technology & Aperture area & HTF & $\begin{array}{l}\text { Operating } \\
\text { conditions }\end{array}$ & $\begin{array}{l}\text { Efficiency/ } \\
\text { system cost }\end{array}$ & Other information \\
\hline $\begin{array}{l}\text { Ipswich, Queensland, Australia, } \\
2007 \text { (Refs. } 94 \text { and 95) }\end{array}$ & $300 \mathrm{~kW}_{\mathrm{r}}$ & Cooling (commercian) & PTC & $570 \mathrm{~m}^{2}$ & Thermal oil & $\ldots$ & $\ldots$ & Double effect VAM \\
\hline $\begin{array}{l}\text { New South Wales, Australia } \\
2008 \text { (Refs. 95-97) }\end{array}$ & $175 \mathrm{~kW}$ & Cooling (demonstration) & PTC & $165 \mathrm{~m}^{2}$ & $\begin{array}{l}\text { Pressurized } \\
\text { water }\end{array}$ & $\ldots$ & $\ldots$ & $\begin{array}{l}\text { Broad LiBr- } \mathrm{H}_{2} \mathrm{O} \\
\text { double stage } \\
\text { absorption chiller }\end{array}$ \\
\hline $\begin{array}{l}\text { Muni Seva Ashram, Gujarat, } \\
\text { India, } 2008 \text { (Refs. } 98 \text { and 99) }\end{array}$ & 351 kWr & Cooling (for hospital) & Scheffler dish & $1250 \mathrm{~m}^{2}$ & Steam & $167^{\circ} \mathrm{C}, 8.5$ bar & Cost: $\$ 200 k$ & $\begin{array}{l}\text { Double effect VAM; } \\
\text { Thermax chiller }\end{array}$ \\
\hline $\begin{array}{l}\text { Downey, California, USA, } 2009 \\
\text { (Ref. 100) }\end{array}$ & $35 \mathrm{~kW}_{\mathrm{r}}$ & Cooling & PTC (SopoNova) & Footprint: $85 \mathrm{~m}^{2}$ & Water & $88^{\circ} \mathrm{C}$ & $\ldots$ & $\begin{array}{r}\text { Installed with a CPVT } \\
\text { array for electricity }\end{array}$ \\
\hline
\end{tabular}




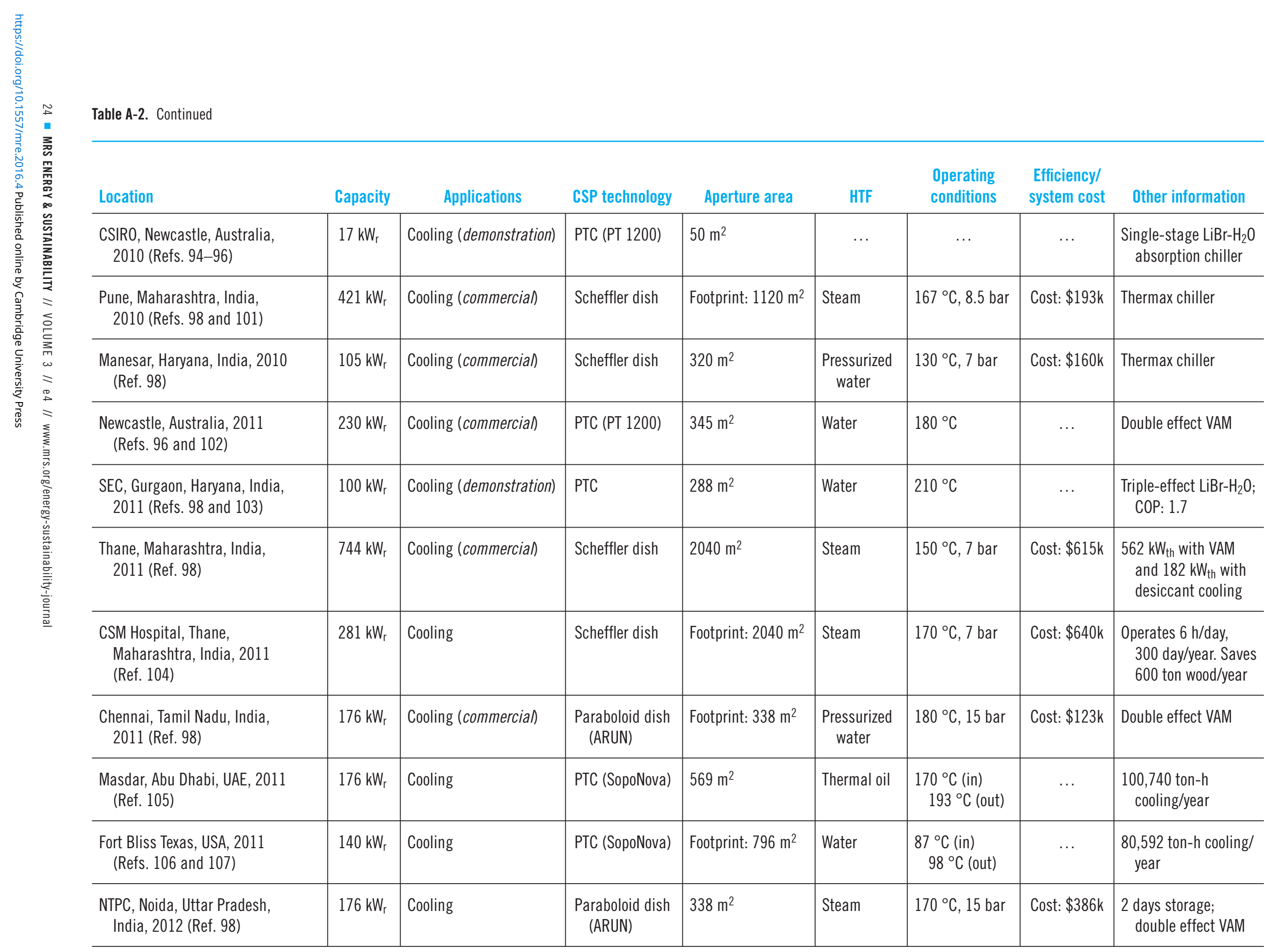


Table A-2. Continued

\begin{tabular}{|c|c|c|c|c|c|c|c|c|}
\hline Location & Capacity & Applications & CSP technology & Aperture area & HTF & $\begin{array}{l}\text { Operating } \\
\text { conditions }\end{array}$ & $\begin{array}{l}\text { Efficiency/ } \\
\text { system cost }\end{array}$ & Other information \\
\hline $\begin{array}{l}\text { NPCIL, Kota, Rajasthan, India, } \\
2013 \text { (Ref. 98) }\end{array}$ & $351 \mathrm{~kW}_{\mathrm{r}}$ & Cooling (commercial) & PTC & $641 \mathrm{~m}^{2}$ & $\begin{array}{l}\text { Pressurized } \\
\text { water }\end{array}$ & $200^{\circ} \mathrm{C}, 17$ bar & Cost: $\$ 378 \mathrm{k}$ & $\begin{array}{l}\text { Triple effect Thermax } \\
\text { VAM }\end{array}$ \\
\hline $\begin{array}{l}\text { Honeywell Tech, Hyderabad, } \\
\text { India, } 2013 \text { (Ref. 98) }\end{array}$ & $351 \mathrm{~kW}_{\mathrm{r}}$ & Cooling (commercial) & PTC & $821 \mathrm{~m}^{2}$ & $\begin{array}{l}\text { Pressurized } \\
\text { water }\end{array}$ & $165^{\circ} \mathrm{C}, 17 \mathrm{bar}$ & Cost: $\$ 330 \mathrm{k}$ & $\begin{array}{l}\text { Triple effect Thermax } \\
\text { VAM }\end{array}$ \\
\hline $\begin{array}{l}\text { Gauteng, South Africa, } 2014 \\
\text { (Refs. } 108 \text { and 109) }\end{array}$ & $330 \mathrm{~kW}_{\mathrm{r}}$ & Cooling (demonstration) & Linear Fresnel & $484 \mathrm{~m}^{2}$ & $\begin{array}{l}\text { Pressurized } \\
\text { water }\end{array}$ & $180^{\circ} \mathrm{C}$ (out) & $\ldots$ & Double effect VAM \\
\hline $\begin{array}{l}\text { Tianjin University, Tianjin, } \\
\text { China (Ref. 110) }\end{array}$ & $250 \mathrm{~kW}$ & Cooling $(R \& D)$ & PTC & $225 \mathrm{~m}^{2}$ & Synthetic oil & $150-205^{\circ} \mathrm{C}$ & $\ldots$ & $\begin{array}{l}\mathrm{NH}_{3} \cdot \mathrm{H}_{2} \mathrm{O} \text { absorption } \\
\quad \text { chiller }\end{array}$ \\
\hline $\begin{array}{l}\text { Tai'an Taishan, China } \\
\text { (Ref. 111) }\end{array}$ & $40 \mathrm{~kW}_{\mathrm{r}}$ & Cooling (commercial) & PTC & $160 \mathrm{~m}^{2}$ & Thermal oil & $200^{\circ} \mathrm{C}$ (max) & $\ldots$ & $\begin{array}{l}\text { Ammonia absorption } \\
\text { chiller }\end{array}$ \\
\hline $\begin{array}{l}\text { TVS Suzuki, Chennai, Tamil Nadu, } \\
\text { India (Refs. } 112 \text { and 113) }\end{array}$ & $300 \mathrm{~kW}_{\mathrm{r}}$ & Cooling (commercial) & Scheffler dish & $960 \mathrm{~m}^{2}$ & Water & $150^{\circ} \mathrm{C}$ & $\ldots$ & Thermax chiller \\
\hline $\begin{array}{l}\text { Abu Dhabi, UAE (Refs. } 114 \\
\text { and 115) }\end{array}$ & $88 \mathrm{~kW}_{\mathrm{r}}$ & Cooling (commercial) & $\begin{array}{l}\text { Linear Fresnel } \\
\text { (Chromasun) }\end{array}$ & $93 \mathrm{~m}^{2}$ & Water & $195^{\circ} \mathrm{C}, 14$ bar & $\ldots$ & $\begin{array}{c}\text { Thermax double effect } \\
\text { absorption chiller }\end{array}$ \\
\hline Phoenix, Arizona, USA (Ref. 116) & $702 \mathrm{~kW}_{\mathrm{r}}$ & Cooling (commercial) & PTC (PTM-x) & $4243 \mathrm{~m}^{2}$ & Thermal oil & $\ldots$ & $\ldots$ & Double effect VAM \\
\hline
\end{tabular}

a $\mathrm{kW}_{\mathrm{r}}$ used to distinguish cooling capacity from thermal capacity $\left(\mathrm{kW}_{\mathrm{th}}\right)$. 


\begin{tabular}{|c|c|c|c|c|c|c|c|c|}
\hline Location & Capacity & Applications & CSP technology & $\begin{array}{l}\text { Aperture } \\
\text { area }\end{array}$ & HTF \& WF & $\begin{array}{l}\text { Operating } \\
\text { conditions }\end{array}$ & $\begin{array}{l}\text { Efficiency/system } \\
\text { information }\end{array}$ & $\begin{array}{l}\text { Other information } \\
\text { (cycle, storage) }\end{array}$ \\
\hline $\begin{array}{l}\text { Riyadh, Saudi Arabia, } \\
1984 \text { (Refs. } 124 \\
\text { and 125) }\end{array}$ & $53 \mathrm{~kW}_{\mathrm{e}}$ & Electricity & Parabolic dish & $227 \mathrm{~m}^{2}$ & WF: hydrogen & $800^{\circ} \mathrm{C}, 150$ bar & $\begin{array}{l}\text { Solar-to-electric: } \\
23 \%\end{array}$ & $\begin{array}{l}\text { Stirling (United } \\
\text { Stirling Model } \\
\text { 4-275) }\end{array}$ \\
\hline $\begin{array}{l}\text { Vanguard, California, } \\
\text { USA, } 1984 \text { (Refs. } 124 \\
\text { and 125) }\end{array}$ & $25 \mathrm{~kW}_{\mathrm{e}}$ & Electricity & Parabolic dish & $88 \mathrm{~m}^{2}$ & WF: hydrogen & $810^{\circ} \mathrm{C}, 200 \mathrm{bar}$ & $\begin{array}{l}\text { Solar-to-electric: } \\
29.4 \% \\
\text { (@ } 760{ }^{\circ} \mathrm{C} \\
\text { gas temp) }\end{array}$ & $\begin{array}{l}\text { Stirling (United } \\
\text { Stirling Model } \\
\text { 4-95 Mk II) }\end{array}$ \\
\hline $\begin{array}{l}\text { McDonnell Douglas, } \\
\text { California, USA, } 1985 \\
\text { (Refs. } 124 \text { and 125) }\end{array}$ & $25 \mathrm{~kW}_{\mathrm{e}}$ & Electricity & Parabolic dish & $91 \mathrm{~m}^{2}$ & WF: hydrogen & $720^{\circ} \mathrm{C}, 200$ bar & $\begin{array}{l}\text { Solar-to-electric: } \\
29-30 \%\end{array}$ & $\begin{array}{l}\text { Stirling (United } \\
\text { Stirling Model } \\
\text { 4-95 Mk II) }\end{array}$ \\
\hline $\begin{array}{l}\text { PSA, Almeria, Spain, } \\
1991 \text { (Ref. 125) }\end{array}$ & $9 \mathrm{~kW}_{\mathrm{e}}$ & Electricity & Parabolic dish & $44 \mathrm{~m}^{2}$ & WF: helium & $\begin{array}{c}630-850{ }^{\circ} \mathrm{C} \\
150 \text { bar }\end{array}$ & $\begin{array}{l}\text { Solar-to-electric: } \\
20 \%\end{array}$ & $\begin{array}{l}\text { Stirling } \\
\text { (SOLO GmbH) }\end{array}$ \\
\hline $\begin{array}{l}\text { Miyako, Japan, } 1992 \\
\quad \text { (Ref. 125) }\end{array}$ & $9 \mathrm{~kW}_{\mathrm{e}}$ & Electricity & Parabolic dish & $44 \mathrm{~m}^{2}$ & WF: helium & $\begin{array}{l}683-780^{\circ} \mathrm{C}, 145 \\
\text { bar }\end{array}$ & $\begin{array}{l}\text { Solar-to-electric: } \\
16 \% @ \\
900 \mathrm{~W} / \mathrm{m}^{2}\end{array}$ & Stirling (Aisin Seiki) \\
\hline $\begin{array}{l}\text { California, USA, } 1992 \\
\quad \text { (Ref. 125) }\end{array}$ & $8 \mathrm{~kW}_{\mathrm{e}}$ & Electricity & Parabolic dish & $42 \mathrm{~m}^{2}$ & WF: helium & $\begin{array}{l}629-675^{\circ} \mathrm{C}, 40 \\
\text { bar }\end{array}$ & $\begin{array}{l}\text { Solar-to-electric: } \\
19 \% @ \\
950 \mathrm{~W} / \mathrm{m}^{2}\end{array}$ & $\begin{array}{l}\text { Stirling (Sunpower/ } \\
\text { CPG) }\end{array}$ \\
\hline $\begin{array}{l}\text { Lausanne, Switzerland, } \\
2001 \text { (Ref. 204) }\end{array}$ & $15 \mathrm{~kW}_{\mathrm{e}}$ & Electricity & Linear Fresnel & $100 \mathrm{~m}^{2}$ & $\begin{array}{l}\text { HTF: water, WF: } \\
\text { R123/R134 }\end{array}$ & $120-150^{\circ} \mathrm{C}$ & $\ldots$ & ORC \\
\hline $\begin{array}{l}\text { Seville Engineering } \\
\text { School, Seville, Spain, } \\
2004 \text { (Ref. 126) }\end{array}$ & $10 \mathrm{~kW}_{\mathrm{e}}$ & Electricity $(R \& D)$ & Parabolic dish & $64 \mathrm{~m}^{2}$ & WF: hydrogen & $\ldots$ & $\begin{array}{l}\text { Peak solar-to- } \\
\text { electric eff: } \\
18 \%\end{array}$ & Stirling \\
\hline $\begin{array}{l}\text { Nanjing, China, } 2005 \\
\text { (Refs. } 127 \text { and 128) }\end{array}$ & $70 \mathrm{~kW}_{\mathrm{e}}$ & $\begin{array}{l}\text { Electricity } \\
\text { (demonstration) }\end{array}$ & $\begin{array}{l}\text { Heliostat/power } \\
\text { tower }\end{array}$ & $640 \mathrm{~m}^{2}$ & WF: air & $\begin{array}{l}900-1000^{\circ} \mathrm{C} \\
\text { (out), } \\
4 \text { bar (in) }\end{array}$ & System eff: $22 \%$ & $\begin{array}{l}\text { Brayton (Honeywell } \\
\text { Parallon 75) }\end{array}$ \\
\hline
\end{tabular}




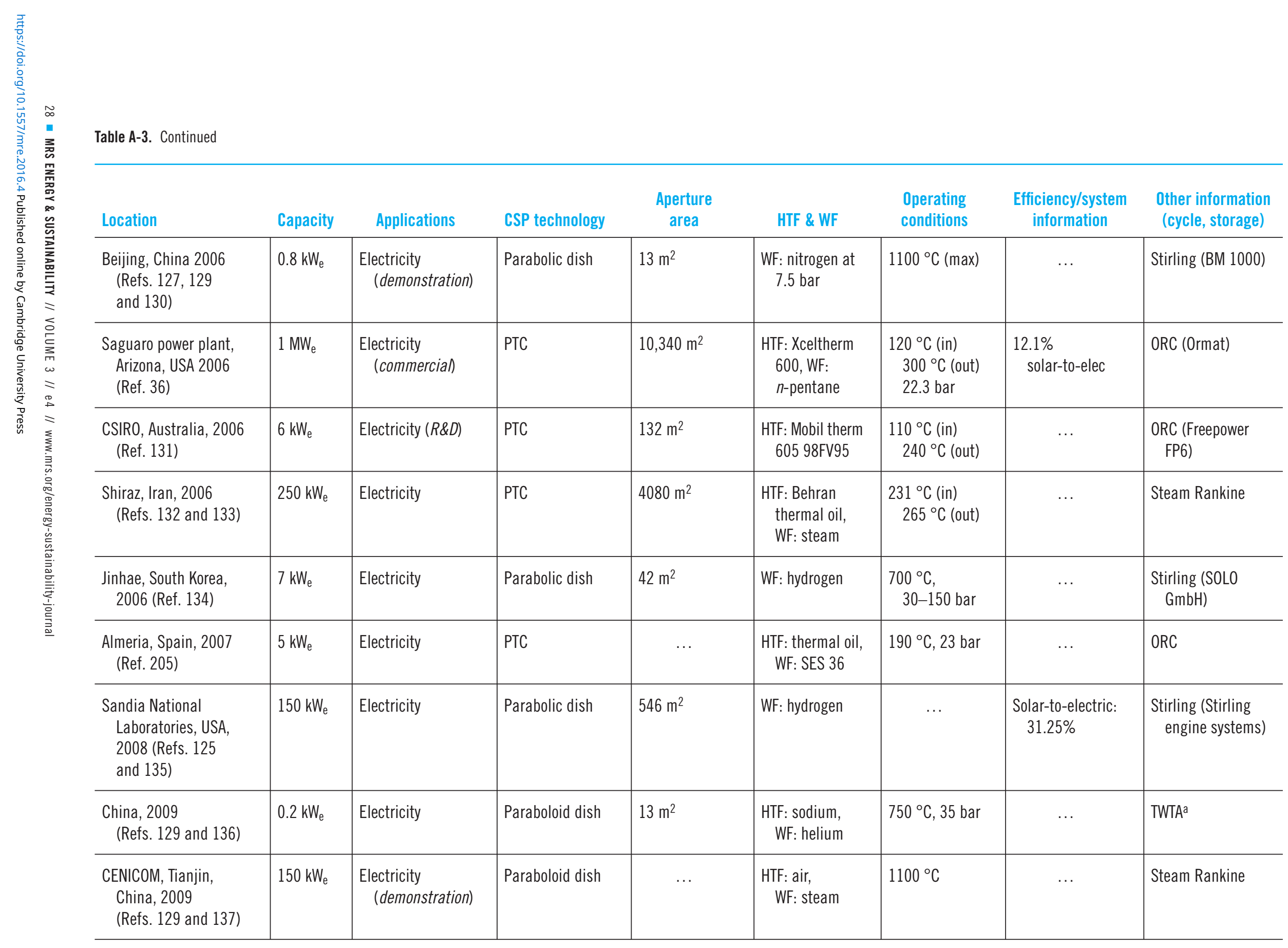


Table A-3. Continued

\begin{tabular}{|c|c|c|c|c|c|c|c|c|}
\hline Location & Capacity & Applications & CSP technology & $\begin{array}{l}\text { Aperture } \\
\text { area }\end{array}$ & HTF \& WF & $\begin{array}{l}\text { Operating } \\
\text { conditions }\end{array}$ & $\begin{array}{l}\text { Efficiency/system } \\
\text { information }\end{array}$ & $\begin{array}{l}\text { Other information } \\
\text { (cycle, storage) }\end{array}$ \\
\hline $\begin{array}{l}\text { Solar Energy Center, } \\
\text { Gurgaon, India, } 2010 \\
\text { (Refs. 138-141, 206) }\end{array}$ & $6.6 \mathrm{~kW}_{\mathrm{e}}$ & Electricity $(R \& D)$ & Parabolic dish & $45 \mathrm{~m}^{2}$ & WF: helium & $500-1200^{\circ} \mathrm{C}$ & $\ldots$ & Stirling (3 units) \\
\hline $\begin{array}{l}\text { Cyprus island, Turkey, } \\
2010 \text { (Refs. } 142 \\
\text { and 143) }\end{array}$ & $18 \mathrm{~kW}_{\mathrm{e}}$ & Electricity & PTC (PTC 1800) & $216 \mathrm{~m}^{2}$ & $\begin{array}{l}\text { HTF: water, } \\
\text { WF: R245fa }\end{array}$ & $76-107^{\circ} \mathrm{C}$ & $\ldots$ & ORC (Electratherm) \\
\hline $\begin{array}{l}\text { CSIR0, Newcastle, } \\
\text { Australia, } 2011 \\
\text { (Refs. } 144 \text { and 145) }\end{array}$ & $200 \mathrm{~kW}_{\mathrm{e}}$ & Electricity $(R \& D)$ & $\begin{array}{l}\text { Heliostat/power } \\
\text { tower }\end{array}$ & $4,000 \mathrm{~m}^{2}$ & WF: air & $900-1500^{\circ} \mathrm{C}$ & $\ldots$ & Brayton \\
\hline $\begin{array}{l}\text { Shive, Pune, } \\
\text { Maharashtra, India, } \\
2011 \text { (Refs. 146-148) }\end{array}$ & $256 \mathrm{~kW}_{\mathrm{e}}$ & $\begin{array}{l}\text { Electricity } \\
\text { (demonstration) }\end{array}$ & PTC (Thermax) & $\begin{array}{l}\text { Land occupied: } \\
12,140 \mathrm{~m}^{2}\end{array}$ & HTF: steam & $\ldots$ & Cost: $\$ 2.4$ million & $\begin{array}{l}\text { ORC; solar-biomass } \\
\text { hybrid plant }\end{array}$ \\
\hline $\begin{array}{l}\text { Daegu, South Korea, } \\
2011 \text { (Refs. } 149 \\
\text { and 150) }\end{array}$ & 200 kWe & Electricity $(R \& D)$ & $\begin{array}{l}\text { Heliostat/power } \\
\text { tower }\end{array}$ & $1800 \mathrm{~m}^{2}$ & $\begin{array}{l}\text { Air (in receiver), } \\
\text { WF: steam }\end{array}$ & $700^{\circ} \mathrm{C}$ (out) & $\ldots$ & Steam Rankine \\
\hline $\begin{array}{l}\text { TULIP II, Almeria, Spain, } \\
2011 \text { (Refs. 151-154) }\end{array}$ & $100 \mathrm{~kW}_{\mathrm{e}}$ & Electricity $(R \& D)$ & $\begin{array}{l}\text { Heliostat/power } \\
\text { tower }\end{array}$ & $\begin{array}{l}\text { Footprint: } \\
2000 \mathrm{~m}^{2}\end{array}$ & WF: air & $\begin{array}{r}950^{\circ} \mathrm{C} \text { (turbine } \\
\text { inlet), } 4.5 \text { bar }\end{array}$ & $\ldots$ & $\begin{array}{l}\text { Brayton (AORA } \\
\text { TULIP) }\end{array}$ \\
\hline $\begin{array}{l}\text { Dahan power plant, } \\
\text { China. } 2012 \\
\text { (Refs. } 155 \text { and 156) }\end{array}$ & $1 \mathrm{MW}_{\mathrm{e}}$ & $\begin{array}{l}\text { Electricity } \\
\text { (demonstration) }\end{array}$ & $\begin{array}{l}\text { Heliostat/power } \\
\text { tower }\end{array}$ & $10,000 \mathrm{~m}^{2}$ & WF: steam & $\begin{array}{l}104^{\circ} \mathrm{C} \text { (in) } \\
400^{\circ} \mathrm{C} \text { (out), } \\
25 \text { bar }\end{array}$ & $16 \%$ solar-to-elec & Steam Rankine \\
\hline $\begin{array}{l}\text { Wushenqi, Ordos, } \\
\text { China, } 2012 \\
\text { (Refs. } 157 \text { and 158) }\end{array}$ & $100 \mathrm{~kW}_{\mathrm{e}}$ & $\begin{array}{l}\text { Electricity } \\
\quad \text { (demonstration) }\end{array}$ & Parabolic dish & $550 \mathrm{~m}^{2}$ & WF: hydrogen & $\ldots$ & $\begin{array}{l}26-30 \% \\
\quad \text { solar-to-elec }\end{array}$ & Stirling (Cleanergy) \\
\hline $\begin{array}{l}\text { Augustin Fresnel 1, } \\
\text { France, } 2012 \\
\text { (Refs. } 159 \text { and 160) }\end{array}$ & $250 \mathrm{~kW}_{\mathrm{e}}$ & Electricity (pilot) & Linear Fresnel & $\ldots$ & $\begin{array}{l}\text { HTF: water, } \\
\text { WF: steam }\end{array}$ & $\begin{array}{c}300^{\circ} \mathrm{C} \text { (out) } \\
100 \text { bar }\end{array}$ & $\ldots$ & $\begin{array}{l}\text { Steam Rankine; } \\
0.25 \text { h pressurized } \\
\text { water storage }\end{array}$ \\
\hline
\end{tabular}




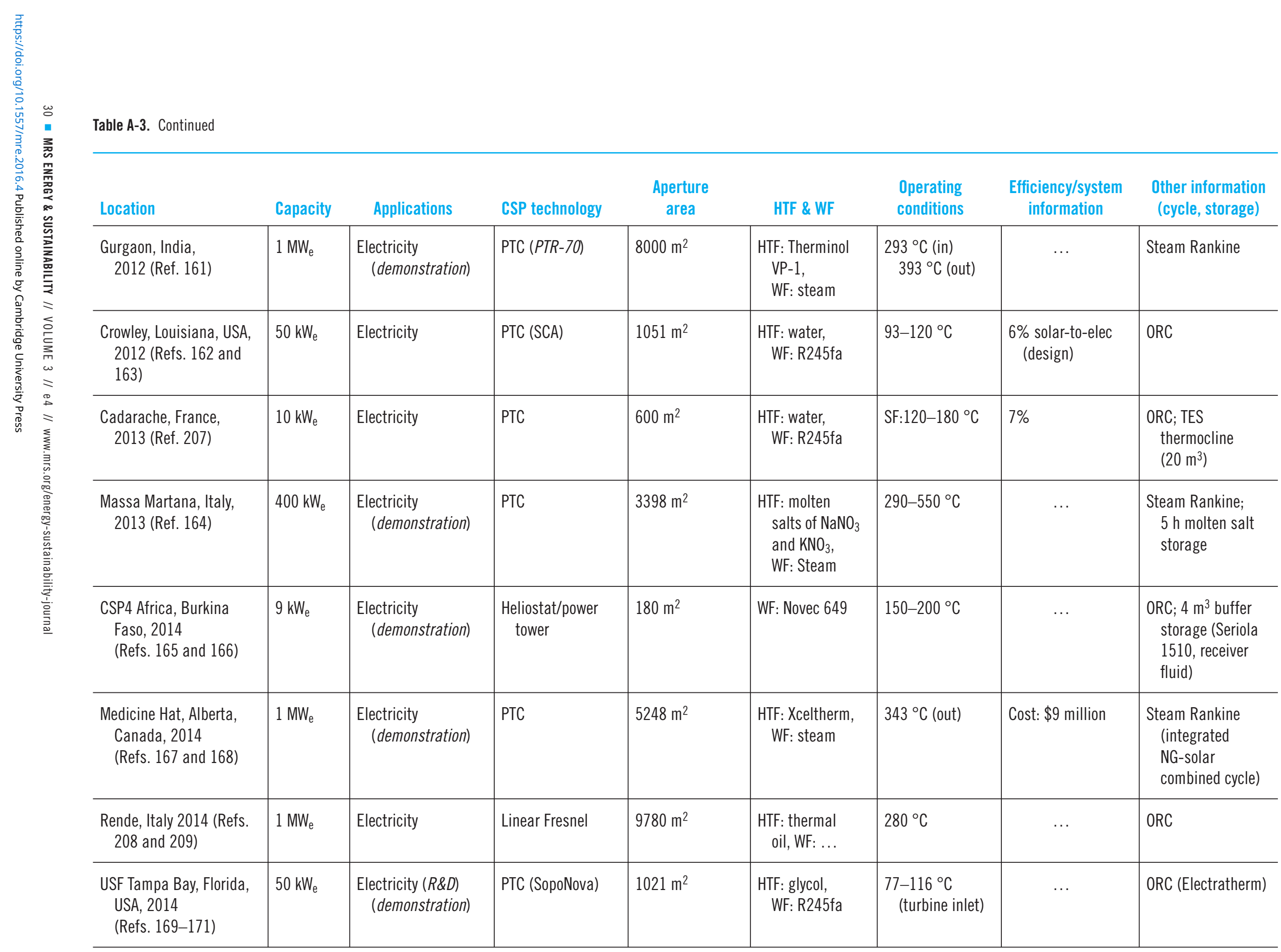


Table A-3. Continued

\begin{tabular}{|c|c|c|c|c|c|c|c|c|}
\hline Location & Capacity & Applications & CSP technology & $\begin{array}{l}\text { Aperture } \\
\text { area }\end{array}$ & HTF \& WF & $\begin{array}{l}\text { Operating } \\
\text { conditions }\end{array}$ & $\begin{array}{l}\text { Efficiency/system } \\
\text { information }\end{array}$ & $\begin{array}{l}\text { Other information } \\
\text { (cycle, storage) }\end{array}$ \\
\hline $\begin{array}{l}\text { VIT, Vellore, } \\
\quad \text { Tamil Nadu, India112 }\end{array}$ & $9 \mathrm{~kW}_{\mathrm{e}}$ & $\begin{array}{l}\text { Electricity } \\
\quad \text { (demonstration) }\end{array}$ & Parabolic dish & $57 \mathrm{~m}^{2}$ & WF: helium & $\begin{array}{l}650^{\circ} \mathrm{C}, \\
20-150 \text { bar }\end{array}$ & $\ldots$ & $\begin{array}{l}\text { Stirling (single } \\
\text { acting, } 160 \mathrm{cc} \\
\text { swept volume) }\end{array}$ \\
\hline $\begin{array}{l}\text { Heliofocus Ramat } \\
\text { Hovav, Israel|172-174 }\end{array}$ & $\begin{array}{l}500 \mathrm{~kW}_{\mathrm{e}} \\
\text { (Ref. } \\
210 \text { ) }\end{array}$ & $\begin{array}{l}\text { Electricity } \\
\quad \text { (demonstration) }\end{array}$ & Parabolic dish & $2000 \mathrm{~m}$ & $\begin{array}{l}\text { HTF: air, } \\
\text { WF: steam }\end{array}$ & $1,000^{\circ} \mathrm{C}$ & 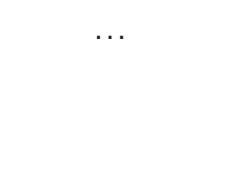 & $\begin{array}{l}\text { Steam Rankine } \\
\text { (bottoming CC } \\
\text { fossil fuel power } \\
\text { plant) }\end{array}$ \\
\hline
\end{tabular}

a Traveling-wave thermo-acoustic (TWTA) heat engine and electricity generator.

Table A-4. Identified micro-CSP/micro-CST systems (combined applications) globally, sorted by deployment year. ${ }^{\text {a }}$

\begin{tabular}{|c|c|c|c|c|c|c|c|c|}
\hline Location & Capacity & Applications & $\begin{array}{c}\text { CSP } \\
\text { technology }\end{array}$ & $\begin{array}{l}\text { Aperture } \\
\text { area }\end{array}$ & HTF \& WF & $\begin{array}{l}\text { Operating } \\
\text { conditions }\end{array}$ & $\begin{array}{l}\text { Efficiency/ } \\
\text { system cost }\end{array}$ & Other information \\
\hline $\begin{array}{l}\text { Kuwait city, } \\
\text { Kuwait, 1981 } \\
\text { (Refs. 211-213) }\end{array}$ & $100 \mathrm{~kW}_{\mathrm{e}}$ & $\begin{array}{l}\text { CHP (heat for } \\
\text { desalination) + } \\
\text { irrigation }\end{array}$ & Parabolic dish & $1100 \mathrm{~m}^{2}$ & $\begin{array}{l}\text { HTF: synthetic } \\
\text { oil, WF: } \\
\text { toluene }\end{array}$ & 15 bar & $31 \%$ (combined) & $\begin{array}{l}\text { ORC; Thermocline } \\
\text { storage } 15 \mathrm{~m}^{2}\end{array}$ \\
\hline $\begin{array}{r}\text { Japan, } 2002 \\
\text { (Ref. 214) }\end{array}$ & $\begin{array}{l}8 \mathrm{~kW}_{\mathrm{e}} \\
17 \mathrm{~kW}_{\mathrm{th}}\end{array}$ & $\begin{array}{r}\text { Electricity, hot } \\
\text { water }(R \& D)\end{array}$ & $\begin{array}{l}\text { Nonevacuated } \\
\text { CPC }\end{array}$ & $30 \mathrm{~m}^{2}$ & $\begin{array}{l}\text { HTF: water, } \\
\text { WF: water; } \\
\text { R-113 }\end{array}$ & $140-180^{\circ} \mathrm{C}$ & $\begin{array}{l}\text { 20\% (solar-to- } \\
\text { elec); } 64 \% \text { (solar- } \\
\text { to-elec + space } \\
\text { heating) }\end{array}$ & $\begin{array}{l}\text { Solar pulse turbine; } 200 \mathrm{~L} \\
\text { latent heat storage } \\
\left(\text { mannitol }+\mathrm{CaSO}_{4}\right)\end{array}$ \\
\hline $\begin{array}{l}\text { Dalaman, Turkey, } \\
2003 \text { (Refs. } 215 \\
\text { and 216) }\end{array}$ & $\begin{array}{l}116 \mathrm{~kW}_{\mathrm{th}} \\
140 \mathrm{~kW}_{\mathrm{r}}\end{array}$ & $\begin{array}{l}\text { Process heat } \\
\text { (laundry), } \\
\text { cooling }\end{array}$ & PTC & $360 \mathrm{~m}^{2}$ & Steam & $180^{\circ} \mathrm{C}$ & $\ldots$ & $\begin{array}{l}\text { Double effect absorption } \\
\text { chiller; COP: } 1.2 ; \\
590 \mathrm{~kW} \mathrm{~h} \text { h/day }\end{array}$ \\
\hline $\begin{array}{l}\text { Koachan, Chonburi, } \\
\text { Thailand, } 2006 \\
\text { (Refs. } 179 \text { and 180) }\end{array}$ & $\begin{array}{c}100 \mathrm{~kW}_{\mathrm{th}} \\
10 \mathrm{~kW}_{\mathrm{e}}\end{array}$ & $\begin{array}{c}\text { Electricity, heating } \\
\text { (demonstration) }\end{array}$ & PTC (Solarlite) & $205 \mathrm{~m}^{2}$ & $\begin{array}{l}\text { HTF: steam, } \\
\text { WF: steam }\end{array}$ & $160^{\circ} \mathrm{C}, 6$ bar & $\begin{array}{l}\text { 10\% (thermal- } \\
\text { to-elec) }\end{array}$ & $\begin{array}{l}\text { Steam Rankine; combined } \\
\text { with biomass for night } \\
\text { operation }\end{array}$ \\
\hline
\end{tabular}




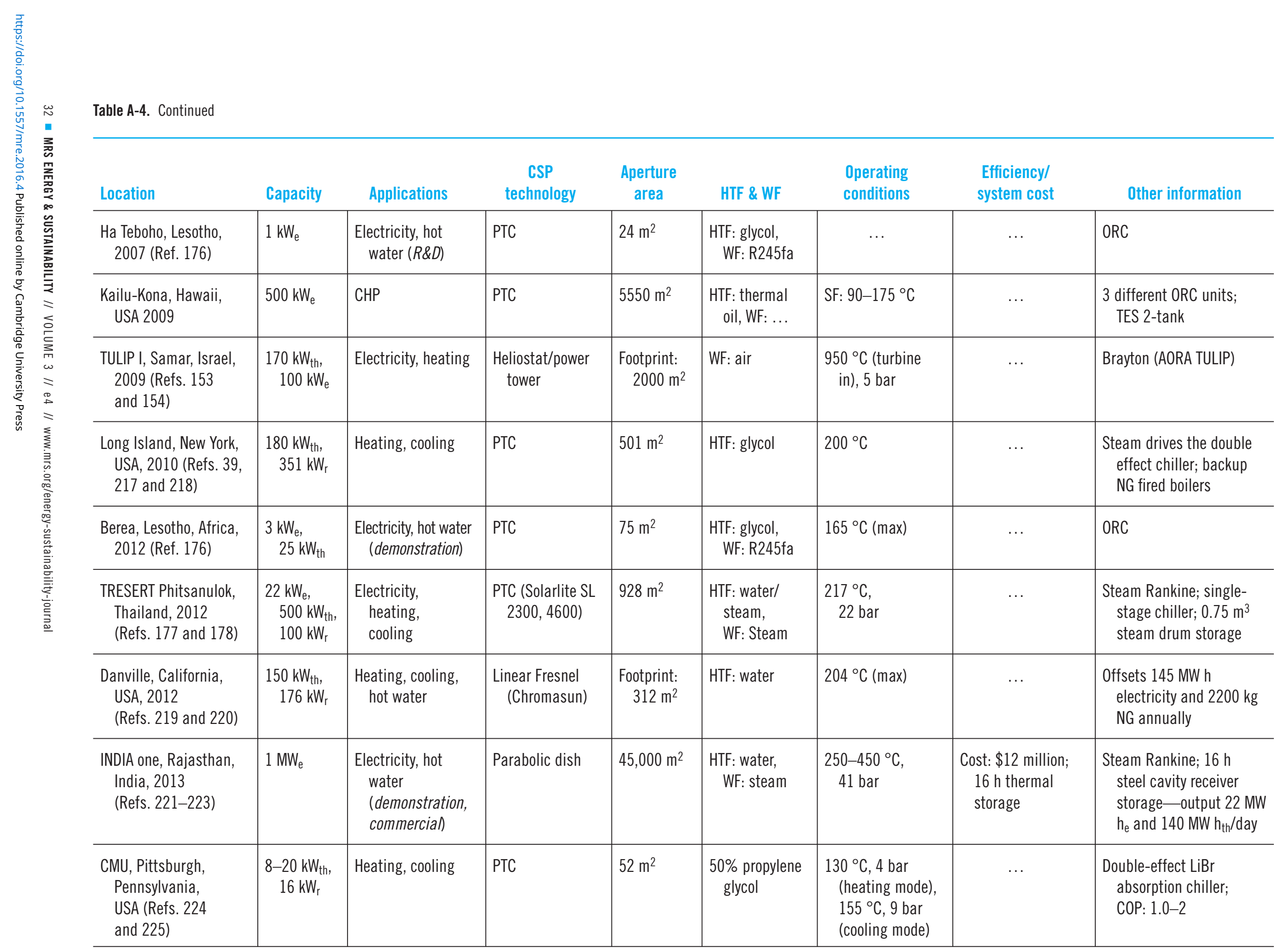

a $\mathrm{kW}_{\mathrm{r}}$ used to distinguish cooling capacity from thermal capacity $\left(\mathrm{kW}_{\mathrm{th}}\right)$. 